Supplement of Biogeosciences, 13, 1767-1786, 2016

http://www.biogeosciences.net/13/1767/2016/

doi:10.5194/bg-13-1767-2016-supplement

(C) Author(s) 2016. CC Attribution 3.0 License.

(c) (i)

Supplement of

\title{
Reviews and Syntheses: Ocean acidification and its potential impacts on marine ecosystems
}

Khan M. G. Mostofa et al.

Correspondence to: Khan M. G. Mostofa (mostofa@tju.edu.cn) and Cong-Qiang Liu (liucongqiang@ vip.skleg.cn)

The copyright of individual parts of the supplement might differ from the CC-BY 3.0 licence. 


\section{Reviews and Syntheses: Ocean acidification and its potential impacts on marine ecosystems}

(1)

4

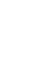

\subsection{Increasing dissolution of atmospheric $\mathrm{CO}_{2}$ to seawater}

The exchange of $\mathrm{CO}_{2}$ between seawater and the atmosphere can take place following different mechanisms and with different features. The outcome is a very varied degree of $\mathrm{CO}_{2}$ uptake from, and/or emission to, the atmosphere, with time scales for variability that are in the daily to seasonal range. The main situations that may be encountered in seawater are listed below.

2.1.1 Sinking or balance of atmospheric $\mathrm{CO}_{2}$ to seawater under sunlight, and emission or balance of $\mathrm{CO}_{2}$ to the atmosphere during the night. This scenario can take place with a time span ranging from minutes to several hours (Biswas et al., 2004; DeGrandpre et al., 1998; Jiang et al., 2011; Nakamura and Nakamori, 2009; Zhang et al., 2013), and two phenomena can be involved: (i) Elevated photosynthesis produces a strong consumption of seawater $\mathrm{CO}_{2}$, thereby decreasing the fugacity of $\mathrm{CO}_{2}\left(f \mathrm{CO}_{2}\right)$ in water and making seawater itself an important sink of atmospheric $\mathrm{CO}_{2}$. Elevated photosynthesis would be associated to a high degree of degradation/respiration of organic matter includingprimary producers (PP) and dissolved organic matter (DOM), which causes a fast recycling of nutrients and provides optimum conditions for the primary productivity to be high. Such a behavior is generally observed in waters with a high degree of eutrophication. (ii) During the night, an elevated degree of degradation/respiration of organic material would substantially increase the $f \mathrm{CO}_{2}$ in seawater, so that $\mathrm{CO}_{2}$ will be released to the atmosphere (Ma and Green, 2004; Xie et al., 2004). The high degree of respiration during the night is made possible by the availability of organic material and, produced by the elevated photosynthetic activity at daytime. Highly eutrophic waters with elevated nutrients that show such a behavior can be found in the Jiulongjiang estuary (Fig. 2a), in Mangrove coastal locations (Biswas et al., 2004), in Luhuitou fringing reef, Sanya Bay, South China Sea (Zhang et al., 2013), in the Gulf of Biscay and the North Sea (Frankignoulle and Borges, 2001), in the coastal seawater, Aodi and Nanwan Bay sites, Taiwan (Jiang et al., 2011), in the California coastal waters during the day time (DeGrandpre et al., 1998), in reef crest algal community (Ishigaki Island) Japan (Nakamura and Nakamori, 2009), in reef crest algal community (Ishigaki Island) Japan (Nakamura and Nakamori, 2009), in branching Acropora (coral) 
community, Ishigaki Island, Japan (Nakamura and Nakamori, 2009), in montiporastellata (coral) community, Ishigaki Island, Japan (Nakamura and Nakamori, 2009), and in Rukan-sho coral reef, Ishigaki Island, Japan (Ohde and van Woesik, 1999). The inner shelf/coastal waters are more likely to act as sinks of atmospheric $\mathrm{CO}_{2}$ during daytime (Chen and Borges, 2009; Zhai et al., 2005).

The optimum conditions for such a situation to be found are associated with high primary production and require a sufficient amount of nutrients and light (Behrenfeld et al., 2002). For example, daytime sinking of atmospheric $\mathrm{CO}_{2}$ can be observed in: in the California coastal waters during the day time (DeGrandpre et al., 1998); in the coastal seawater of the Bay of Bengal in sites (site 3) that are sufficiently rich in nutrients (the same trend is not followed in nutrient-deficient sites) (Akhand et al., 2013), and during the summer period (April-August) in subtropical eutrophic lakes such as Lake Hongfeng and Lake Baihua (Wang et al., 2011). The latter two lakes have both a sufficient amount of nutrients and have high water temperature (e.g. 9-26 ${ }^{\circ} \mathrm{C}$ during the whole year), as a consequence of high sunlight intensity (Li et al., 2013; Long et al., 2013).

The balance between the daytime sinking of atmospheric $\mathrm{CO}_{2}$ and the nighttime

\subsubsection{Emission or balance of $\mathrm{CO}_{2}$ to the atmosphere during daytime, and sinking} or balance of atmospheric $\mathrm{CO}_{2}$ to surface water during the night. This scenario is typically observed in waters with low photosynthetic activity, where there is limited consumption of $\mathrm{CO}_{2}$ by photosynthesis during the day and limited degradation/respiration of organic matter in the night time (Fransson et al., 2004; Kuffner et al., 2008; Yates et al., 2007; Zhai et al., 2005). Such conditions are typically observed in waters that are characterized by a low level of nutrients or sunlight irradiation, and/or in the presence of temporary factors such as sunlight limitation because of cloudy weather or precipitation. The fluxes of $\mathrm{CO}_{2}$ between the atmosphere and seawater could depend for instance on the water temperature, as more elevated daytime temperature would decrease the solubility of $\mathrm{CO}_{2}$ in water and the reverse would happen during the night. The daytime emission of $\mathrm{CO}_{2}$ from seawater would also be favored by the respiration/degradation of organic matter. Such a scenario is often observed in waters where the primary production is limited by the availability of nutrients, even in the presence of relatively elevated 
amounts of organic carbon. These conditions can be found in the Jiulongjiang estuary (Fig. 2a), in the Tampa and Florida Bay (Yates et al., 2007); in the northern South China Sea (Dai et al., 2009), in the salt marshes and mangroves (Chen and Borges, 2009), in the outer shelf/open ocean (Chen and Borges, 2009; Zhai et al., 2005) and in the Coral reef (mesocosm), Moku O Loe, Kaneohe Bay, Hawaii (Kuffner et al., 2008). The availability of nutrients, with typically seasonal time scales, influences photosynthesis under conditions of elevated illumination in the surface layer (light saturation). In contrast, in deeper waters photosynthesis responds on a shorter time scale to variations of incoming irradiance, light attenuation and mixing layer depth (Behrenfeld et al., 2002). night. This scenario (Borges and Frankignoulle, 2003; Goyet and Peltzer, 1997; Kayanne et al., 2005; Nakamura and Nakamori, 2009) is observed when $\mathrm{CO}_{2}$ is produced by degradation/respiration of organic matter (and also by abiotic photodegradation in daytime), and when photosynthesis is unable to uptake the generated carbon dioxide. The consequence is an increase of seawater $f \mathrm{CO}_{2}$ and a subsequent release of the excess $\mathrm{CO}_{2}$ to the atmosphere. Typical reasons for this scenario may be lack or scarcity of nutrients and/or light, the latter because of $e$.g. cloudy weather. Such water characteristics may be found in the Bay of Seine (Borges and Frankignoulle, 2003), in inner estuaries and nearshore coastal areas, or in low-latitude shelves (Chen and Borges, 2009), in the coastal seawater (site 3) of the Bay of Bengal (Akhand et al., 2013), in the equatorial Pacific Ocean that linked to day-time increase in temperature (Goyet and Peltzer, 1997), mostly source in the Southern Ocean surface water at sites WIE and APF2 (Fransson et al., 2004), in coral reef in Ishigaki Island, Japan in summer (Kayanne et al., 2005), and in pocilloporaverrucosa-tabularAcropora (coral) community, Ishigaki Island, Japan (Nakamura and Nakamori, 2009).

2.1.4 Sinking or balance of atmospheric $\mathrm{CO}_{2}$ to surface water during both day and night. The main difference between this scenario and scenario \#2 is that, in the present case, daytime photosynthesis occurs to a higher extent and it is able to deplete seawater $\mathrm{CO}_{2}$, thereby causing a net uptake of carbon dioxide by seawater. Moreover, the organic material generated during the day is not degraded to a sufficient extent in nighttime to make the seawater $f \mathrm{CO}_{2}$ increase above the atmospheric level. As in the case of scenario $\# 2$, such conditions can be observed in water where the primary production is limited by nutrients and/or light. These characteristics can be found in open shelves in temperate and high-latitude regions, during all seasons (Chen and Borges, 2009), in the Belgian coastal seawater (Borges and Frankignoulle, 1999), in surface waters of the Galician upwelling system (Borges and Frankignoulle, 2001), mostly sinking in the Southern Ocean surface water at site SIE1 (Fransson et al., 2004), in the surface seawater (east of Gotland) in the 
115 Baltic Sea (Wesslander et al., 2011), and mostly sinking in coral reef in Ishigaki Island, 116 Japan in winter (Kayanne et al., 2005).

118 2.1.5 Sinking or source or balance of atmospheric $\mathrm{CO}_{2}$ to surface water during the 119 warm period. This scenario generally takes place in highly productive and nutrient-rich 120 waters (Arrigo et al., 2008; Borges and Frankignoulle, 1999; Thomas et al., 2005; Zhai and Dai, 2009; Zhai et al., 2005). During summer $\mathrm{CO}_{2}$ is consumed by the elevated photosynthesis, which takes place under optimum conditions as far as both nutrients and light are concerned (Arrigo et al., 2008). Degradation/respiration of organic matter does not keep pace with photosynthesis, and the decrease of seawater $f \mathrm{CO}_{2}$ causes a net uptake of carbon dioxide from the atmosphere. During the winter season, the reduction of solar intensity and the shorter day-time ensure that respiration/degradation prevail over photosynthesis, thereby increasing the $\mathrm{fCO}_{2}$ in water at levels comparable to or above those of the atmosphere. Under such circumstances, emission of carbon dioxide by seawater can be observed. Wintertime emission of $\mathrm{CO}_{2}$ to the atmosphere is generally found in the South China Sea (Zhai et al., 2009; Zhai et al., 2005; Zhai et al., 2013), in the East China Sea (Shim et al., 2007; Zhai and Dai, 2009), in the Bay of Bengal (Biswas et al., 2004), in coral reef in Ishigaki Island, Japan (Kayanne et al., 2005), in a few sampling sites in North Sea (Thomas et al., 2004), in the Southern Bight of the North Sea (Schiettecatte et al., 2007), in the English Channel and adjacent seawater (Borges and Frankignoulle, 2003), in the Scheldt plume off the Belgian coast (Borges and Frankignoulle, 2002), in the seawater of Northwestern Mediterranean Sea (CopinMontégut et al., 2004), in the mid and outer shelf of US Middle Atlantic Bight (DeGrandpre et al., 2002), in the coastal upwelling system (Gago et al., 2003), mostly sinking in the Gulf of Biscay (Frankignoulle and Borges, 2001), mostly source in the Kaneohe Bay, Oahu, Hawaii (Fagan and Mackenzie, 2007), mostly sinking in the seawater of the Gotland Sea (Kuss et al., 2004; Schneider et al., 2003), mostly sinking in the Chukchi Sea adjacent to the Arctic Ocean (Bates, 2006), mostly source in the Antarctic shelf waters of Southern Ocean (Arrigo et al., 2008), mostly source in the seawater of the Bermuda coral reef system (Bates, 2002), mostly sinking in the Chukchi Sea adjacent to the Arctic Ocean along $65-75^{\circ} \mathrm{N}$ and $150-170^{\circ} \mathrm{W}$ (Bates, 2006), in the Southern Ocean (Arrigo et al., 2008), in the Ross Sea (Sweeney, 2003), and strong sinking during the summer period than in winter in the Gulf of Biscay (Frankignoulle and

2.1.6 Emission or sinking or balance of seawater $\mathrm{CO}_{2}$ to the atmosphere during 151 cold period. This scenario is similar to scenario \#5 and takes place in the similar types of 152 seawaters (Bates, 2006; Borges and Frankignoulle, 2003; Thomas et al., 2004). Such a 153 scenario is observed in a few sampling sites of North Sea (Thomas et al., 2004), in the 
154 Southern Bight of the North Sea (Schiettecatte et al., 2007), in the English Channel and 155 adjacent seawater (Borges and Frankignoulle, 2003), in the South China Sea (Zhai et al., 156 2013), in the coastal seawater in the Bay of Bengal (Biswas et al., 2004) (Biswaste al., 157 2004), in the seawater of Northwestern Mediterranean Sea (Copin-Montégut et al., 2004), 158 in the mid and outer shelf of US Middle Atlantic Bight (DeGrandpre et al., 2002), mostly 159 source in the seawater of the Gotland Sea (Kuss et al., 2004; Schiettecatte et al., 2007), 160 mostly source in the Scheldt plume off the Belgian coast (Borges and Frankignoulle, 161 2002), mostly source in the upper reach of the Pearl River Estuary near South China Sea 162 (Dai et al., 2006), in the Kaneohe Bay, Oahu, Hawaii (Fagan and Mackenzie, 2007), 163 mostly sinking in the Antarctic shelf waters of Southern Ocean (Arrigo et al., 2008), 164 mostly sinking in the seawater of the Bermuda coral reef system (Bates, 2002), mostly 165 sinking in the Chukchi Sea adjacent to the Arctic Ocean along 65-75 $\mathrm{N}$ and $150-170^{\circ} \mathrm{W}$ 166 (Bates, 2006), mostly sinking in East China Sea (Zhai and Dai, 2009), mostly sinking in 167 the Atlantic sector, the Southern Ocean (Chierici et al., 2004), and mostly sinking in coral 168 reef in Ishigaki Island, Japan (Kayanne et al., 2005).

169 Overall, the subtropical-tropical marginal seas and the continental shelves at low 170 latitudes and the equatorial Pacific $\left(14^{\circ} \mathrm{N}-14^{\circ} \mathrm{S}\right)$ act as sources of $\mathrm{CO}_{2}$ to the atmosphere 171 whilst the marginal seas and continental shelves at mid-high latitudes and the temperate 172 oceans between141 and 501 in the both hemispheres acts as a strong sink of atmospheric $173 \mathrm{CO}_{2}$ (Borges, 2005; Borges et al., 2005; Cai et al., 2006; Chen and Borges, 2009; 174 Takahashi et al., 2009). Correspondingly, coral reefs act either as a sourceof $\mathrm{CO}_{2}$ to the 175 atmosphere(Bates, 2002; Gattuso et al., 1999; Ware et al., 1992) or a oceanic sink (Bates, 176 2002; Gattuso et al., 1997; Kraines et al., 1996). But such conclusions might not be 177 precisely true in a variety of seawater that sampled once during the day time at the same 178 location. Six different scenarios of $\mathrm{CO}_{2}$ in seawaters configured that seawater can act as a 179 source or sink or balance of $\mathrm{CO}_{2}$ to the atmosphere which also significantly varied with 180 seasons affecting many factors (see the main text). This therefore indicates that the 181 diurnal variation of $\mathrm{CO}_{2}$ is very important for better understanding of the ocean 182 acidification as well as $\mathrm{CO}_{2}$ behavior in the world's oceans, and this issue should be the 183 focus for further study.

2.3 Enhanced PP and respiration due to the effects of global warming and other processes (Some remaining contents of this section)

188 factors, and those which prevail are linked to the nutrient status of water. Photosynthesis

189 is usually favored by enhanced input of terrestrial DOM into water (Bauer et al., 2013; 190 Porcal et al., 2009), but in DOM-rich waters the regeneration of autochthonous DOM and 191 nutrients from PP plays a more important role. In the presence of sufficient light or high 192 WT under GW conditions, such factors can also lead to harmful algal blooms (Fig. S1) 
193 (Mostofa et al., 2013a). A link between DOM or PP and algal blooms or eutrophication may be observed when the regeneration of nutrients $\left(\mathrm{NH}_{4}{ }^{+}, \mathrm{NO}_{3}{ }^{-}\right.$and $\left.\mathrm{NO}_{2}{ }^{-}\right)$is operational (Cai et al., 2011; Mostofa et al., 2013a). In contrast, transformation of nitrogen-containing nutrients to $\mathrm{N}_{2}$ (Doney et al., 2007; Kuypers et al., 2003; Ward, 2013) largely eliminates the connection (Mostofa et al., 2013a).

The primary production and the occurrence of DOM in seawater are linked to several other processes, including: $(i)$ the increase in atmospheric $\mathrm{CO}_{2}$ (Feng et al., 2009; Gruber et al., 2002; Hein and Sand-Jensen, 1997; Le Quéré et al., 2009; Schippers et al., 2004); (ii) the increased input of terrestrial OM and nutrients, because of human-induced alteration of land use (Cai et al., 2006; Smith et al., 1999; Vitousek et al., 1997) and because of enhanced soil erosion rates due to extreme climate weathering (Nearing et al., 2004); (iii) the input of organic contaminants and nutrients from anthropogenic activities (e.g. sewerage, industries, pharmaceuticals, or intensive fish cage farming (Fu et al., 2010; Mostofa et al., 2013a; Nyenje et al., 2010; Pergent - Martini et al., 2006) ; (iv) large ecological changes in forests (Graven et al., 2013) and transportation of OM by weathering, combined with high terrestrial plant productivity induced by increasing atmospheric $\mathrm{CO}_{2}$ (Regnier et al., 2013); (v) atmospheric acid rain/precipitation (notably $\mathrm{HNO}_{3}$ and $\mathrm{H}_{2} \mathrm{SO}_{4}$ ) (Baker et al., 2007; Teira et al., 2013) and (vi) the effects of GW (Fig. S1) (Engel et al., 2012; Feng et al., 2009; Hein and Sand-Jensen, 1997; Mostofa et al., 2013b; Schippers et al., 2004). Many of the described phenomena are mostly susceptible to affect coastal waters which, by the way, host between $15 \%$ and $30 \%$ of the oceanic primary production and $80 \%$ of the OM burial (Gattuso et al., 1998). Coastal waters also account for most of the benthic oceanic $\mathrm{CaCO}_{3}$ production, for $20 \%$ of the surface pelagic $\mathrm{CaCO}_{3}$ stock (Balch et al., 2005), and for $50 \%$ of the oceanic $\mathrm{CaCO}_{3}$ deposition (Gattuso et al., 1998).

Some of the above-mentioned factors which affect primary production in seawater are also closely interlinked. For instance, the increase of atmospheric temperature due to GW could enhance DOM leaching from terrestrial soils because of high soil respiration, and the DOM contents in surface waters could increase as a consequence (Porcal et al., 2009). Increased atmospheric $\mathrm{CO}_{2}$ would also increase the turnover rates of soil OM, driven by the enhanced activity of soil microorganisms (Blagodatskaya et al., 2010) and including a higher rate of decomposition of older and fresh plant residues (Blagodatskaya et al., 2010; Dorodnikov M, 2011). Note that elevated $\mathrm{CO}_{2}$ was shown to enhance soil OM mineralization by $83-218 \%$ in a simulated wetland (Wolf et al., 2007). A net increase of $\mathrm{C}$ emissions to the atmosphere would thus be induced by enhanced respiration of soil OM under global warming condition (Davidson and Janssens, 2006; Knorr et al., 2005).

230 The increase of net primary production in seawater is responsible for the gradual increase 231 of $\mathrm{CO}_{2}$ in the surface seawater of some oceans, including the ice-free Arctic Ocean Basin 
232 (Cai et al., 2010), the area near the Canary Islands (ESTOC), located in the northeast 233 Atlantic subtropical gyre (González-Dávila et al., 2003), and in the Northern Hemisphere 234 (Graven et al., 2013). Enrichment of surface seawater in $\mathrm{CO}_{2}$ means that oceanic water 235 behaves less effectively as a sink and could even become a net $\mathrm{CO}_{2}$ source to the 236 atmosphere, as is presently the case for the equatorial Pacific (Takahashi et al., 2009). Average rates of increase in surface-water $f \mathrm{CO}_{2}$ have been quantified, on the basis of deseasonalized data, as $1.5 \mu \mathrm{atm} \mathrm{y}^{-1}$. The basin- specific rates varied between $1.2 \pm 0.5$ and 2.1 $\pm 0.4 \mu \mathrm{atm} \mathrm{y}^{-1}$ over the North Atlantic, North and South Pacific and Southern Oceans, which cover about $27 \%$ of the global ocean areas (Takahashi et al., 2002; Takahashi et al., 2009). Furthermore, the role of low-latitude continental shelves as net sources of $\mathrm{CO}_{2}$ to the atmosphere is thought to be a consequence of both $\mathrm{GW}$ that increases WT and to higher inputs of terrestrial organic carbon (Cai et al., 2006; Corbière et al., 2007). The effect of $\mathrm{GW}$ on the release of $\mathrm{CO}_{2}$ to the atmosphere is related to a series of processes, including lower solubility of $\mathrm{CO}_{2}$ in warmer waters, increased stratification and the effects on primary productivity (Keeling, 2005). Coastal waters are also more susceptible to acidification than the open ocean, because of the effects of eutrophication (such as emission of $\mathrm{CO}_{2}$ by respiration and mineralization of organic $\mathrm{N}$ and $\mathrm{P}$ ) that decreases the buffering capacity of seawater. The combination of increasing atmospheric $\mathrm{CO}_{2}$ and of processes occurring in seawater produces different critical scenarios, which are observed for $\mathrm{CO}_{2}$ emissions from seabed and for sinking of anthropic atmospheric $\mathrm{CO}_{2}$ to seawater (see also supplementary section) (Borges and Gypens, 2010; Cai et al., 2011; Dore et al., 2009). Moreover, changes in the biogenic carbon flow in response to sea surface warming have the potential to reduce the transfer of primary produced OM to higher trophic levels (Laws et al., 2000; VázquezDomínguez et al., 2007; Wohlers et al., 2009). Such processes would weaken the ocean's biological carbon pump and would provide a positive feedback to the rise of atmospheric

\subsubsection{Impacts of nitrification-denitrification and sulfate reduction on acidification}

Nitrification $\left(\mathrm{NH}_{4}^{+} \rightarrow \mathrm{NO}_{2}^{-} \rightarrow \mathrm{NO}_{3}^{-}\right.$or $\left.\mathrm{NH}_{4}^{+}+2 \mathrm{O}_{2} \rightarrow \mathrm{NO}_{3}^{-}+2 \mathrm{H}^{+}+\mathrm{H}_{2} \mathrm{O}\right)$ (Doney et al., 2007) caused by ammonia-oxidizing bacteria, such as Nitrosomonas and Nitrobacter (Martens-Habbena et al., 2009) can contribute to acidification, and it is for instance partially responsible for the acidification of coastal seawater (Doney et al., 2007). Denitrification $\left(\mathrm{NO}_{3}{ }^{-} \rightarrow \mathrm{NO}_{2}{ }^{-} \rightarrow \mathrm{NO} \rightarrow \mathrm{N}_{2} \mathrm{O} \rightarrow \mathrm{N}_{2}\right.$ ), caused by denitrifying bacteria (Pan et al., 2013) is an important process that occurs in oxygen minimum zones (OMZs) and accounts for approximately $71 \%$ of the nitrogen loss, while anaerobic ammonium oxidation (anammox) accounts for the remaining 29\% (Ward, 2013). An important issue is that increasing atmospheric $\mathrm{CO}_{2}$ is expected to significantly modify the occurrence of microorganisms in oceanic water and to favor global $\mathrm{N}_{2}$ fixation and 
271 possibly denitrification, probably at the expense of nitrification (Hutchins et al., 2013). 272 Denitrification stimulates the acidification by producing an effective total alkalinity flux 273 in seawater (Chen and Wang, 1999; Thomas et al., 2009). However, in addition to the 274 processes already shown, one should consider that ammonium and nitrate also take part 275 to additional cycles. It has been shown that $\mathrm{NO}_{3}{ }^{-}$-supported PP generates alkalinity (106 $276 \mathrm{CO}_{2}+16 \mathrm{NO}_{3}{ }^{-}+138 \mathrm{H}_{2} \mathrm{O} \rightarrow$ organics $+16 \mathrm{OH}^{-}+138 \mathrm{O}_{2}$ ), but the resulting basification 277 would only partially compensate for acidification if nitrate is generated by the oxidation 278 of ammonium according to the reaction $2 \mathrm{NH}_{3}+4 \mathrm{O}_{2} \rightarrow 2 \mathrm{NO}_{3}{ }^{-}+2 \mathrm{H}_{2} \mathrm{O}+2 \mathrm{H}^{+}$; note that 279 ammonium oxidation to nitrate yields $2 \mathrm{H}^{+}$per processed $\mathrm{NH}_{4}{ }^{+}$, while incorporation of 280 nitrate into organic nitrogen only consumes one $\mathrm{H}^{+}$per nitrate ion processed. On the 281 contrary, $\mathrm{NH}_{4}{ }^{+}$-supported PP eliminates alkalinity according to the overall reaction: 106 $282 \mathrm{CO}_{2}+16 \mathrm{NH}_{4}{ }^{+}+106 \mathrm{H}_{2} \mathrm{O} \rightarrow$ organics $+16 \mathrm{H}^{+}+106 \mathrm{O}_{2}$ (Doney et al., 2007). On the 283 other hand, anaerobic ammonium oxidation $\left(\mathrm{NH}_{4}{ }^{+}+\mathrm{NO}_{2}{ }^{-} \rightarrow \mathrm{N}_{2} \mathrm{H}_{4} \rightarrow \mathrm{N}_{2}\right.$ ) carried out by 284 anammox bacteria (Ward, 2013) is $\mathrm{H}^{+}$-neutral $\left(\mathrm{NH}_{4}{ }^{+}+\mathrm{NO}_{2}{ }^{-} \rightarrow \mathrm{N}_{2}+2 \mathrm{H}_{2} \mathrm{O}\right.$ ).

In addition to potentially affecting the $\mathrm{pH}$ of seawater, the nitrogen cycle processes are also substantially influenced by $\mathrm{pH}$ itself. For instance, nitrification rates decrease to zero at a $\mathrm{pH}$ around 6.0-6.5, where the $\mathrm{NH}_{3}$ substrate is practically all 288 protonated to ammonium (Huesemann et al., 2002). In fact, the proportions of $\mathrm{NH}_{3}$ to $289 \mathrm{NH}_{4}{ }^{+}$and of $\mathrm{PO}_{4}{ }^{3-}$ to $\mathrm{HPO}_{4}{ }^{2-}$ are both very sensitive to small $\mathrm{pH}$ variations around 8.0 290 according to the following equations

$$
\frac{\left[\mathrm{NH}_{3}\right]}{\left[\mathrm{NH}_{4}^{+}\right]}=\frac{k_{a}}{\left[\mathrm{H}^{+}\right]} \quad \text { eq. } 1
$$

293 note that $p K_{a}$ for $\mathrm{NH}_{4}^{+}$is 9.3 and the three $p K_{a} \mathrm{~s}$ for $\mathrm{H}_{3} \mathrm{PO}_{4}$ are 2.2, 7.1 and 12,4, 294 respectively(Zeebe and Wolf-Gladrow, 2001). Moreover, the nitrogen cycle may be 295 closely interlinked with that of carbon. For instance, the anaerobic oxidation of $\mathrm{CH}_{4}$ to $296 \mathrm{CO}_{2}$ is connected either to the reduction of $\mathrm{NO}_{3}{ }^{-}$to $\mathrm{NO}_{2}{ }^{-}$and then $\mathrm{N}_{2}$, or to anammox 297 that yields $\mathrm{N}_{2}$ as well (Haroon et al., 2013). The conversion of $\mathrm{SO}_{4}{ }^{2-}$ into $\mathrm{H}_{2} \mathrm{~S}$, carried out 298 by sulfate-reducing bacteria such as desulfobacterales, desulfovibrionales and 299 syntrophobacterales (Muyzer and Stams, 2008) which can either be emitted to the 300 atmosphere or be buried as pyrite, also significantly increases the total alkalinity (Chen 301 and Wang, 1999). Therefore, denitrification and $\mathrm{SO}_{4}{ }^{2-}$ reduction can raise the buffering 302 capacity of $\mathrm{CO}_{2}$ that stimulates the acidification of seawater (Chen and Wang, 1999; 303 Thomas et al., 2009). Note that each mole of denitrified $\mathrm{N}$ and reduced $\mathrm{SO}_{4}{ }^{2-}$ reduction 304 can release 0.99 and 1.98 mol of total alkalinity, respectively (Chen and Wang, 1999). 
2.4 Direct acidification and stimulation of PP by atmospheric acid rain: Natural

308 Atmospheric acid rain can decrease the $\mathrm{pH}$ of seawater directly, by the input of $\mathrm{HNO}_{3}$ and $\mathrm{H}_{2} \mathrm{SO}_{4}$, and indirectly through the addition of $\mathrm{NH}_{4}{ }^{+}$(Bates and Peters, 2007; Doney et al., 2007). In fact, most of the anthropogenic $\mathrm{NH}_{3}$ and $\mathrm{NH}_{4}{ }^{+}(\sim 98 \%)$ are nitrified to nitrate in the upper ocean releasing $\mathrm{H}^{+}$ions $\left(\mathrm{NH}_{4}{ }^{+}+2 \mathrm{O}_{2} \rightarrow \mathrm{NO}_{3}{ }^{-}+2 \mathrm{H}^{+}+\mathrm{H}_{2} \mathrm{O}\right.$; see also the previous section). This issue causes the effective net atmospheric input of ammonium to be acidic (Doney et al., 2007). A rough estimate shows that direct atmospheric acidic depositions could contribute $2 \%$ to the acidification of surface waters in the subtropical North Atlantic Ocean since the early 1980's (Bates and Peters, 2007).

Another important impact of rainfall in general, including the acidic one is the stimulating effect on primary production, as shown by field observations and experimental simulations (Baker et al., 2007; Paerl and Fogel, 1994; Teira et al., 2013). As discussed earlier, the enhanced primary production can contribute to seawater acidification through increased $\mathrm{CO}_{2}$. Note that atmospheric rainfall can bring nutrients to seawater, including $\mathrm{NO}_{3}^{-}, \mathrm{NH}_{4}{ }^{+}$and $\mathrm{PO}_{4}{ }^{3-}$ (Doney et al., 2007; Paerl and Fogel, 1994), $\mathrm{Fe}^{2+}$ and $\mathrm{Fe}^{3+}$ (Baker et al., 2007; Kieber et al., 2001), dissolved Si (Baker et al., 2007) and other major ions such as $\mathrm{F}^{-}, \mathrm{Cl}^{-}, \mathrm{SO}_{4}{ }^{2-}, \mathrm{K}^{+}, \mathrm{Na}^{+}, \mathrm{Ca}^{2+}, \mathrm{Mg}^{2+}, \mathrm{Co}^{2+}$ and $\mathrm{Zn}^{2+}$ (Baker et al., 2007; Zhang et al., 2007). Other compounds contained in rainwater that could stimulate photosynthesis under definite conditions are $\mathrm{H}_{2} \mathrm{O}_{2}$, aldehydes and organic acids (Sakugawa et al., 1993), as well as other dissolved organic substances (Kieber et al., 2006). In situ incubation experiments demonstrate that chlorophyll $a$ concentration is increased by 2.6 times with the addition of $10 \%$ (v/v) rainwater (Zou et al., 2000). Microcosm experiments on the effect of rainwater addition to natural marine plankton populations also showed an increase in bacterial abundance and production (Teira et al., 2013). Another issue is that rainfall on land can produce an important input of OM and nutrients in seawater via terrestrial runoff. In addition to the possible stimulation of acidification processes, the direct or indirect (though runoff) fertilization of seawater carried out by rain could contribute to the occurrence of harmful algal blooms and to the generation of pathogens (Doney et al., 2007; Flewelling et al., 2005; Sekar et al., 2006; Sunda and Cai, 2012; Teira et al., 2013). 


\section{References}

Akane, S., Makino, S., Hashimoto, N., Yatsuzuka, Y., Kawai Yu, T. K., and Sakugawa, H.: Hydrogen peroxide in the sea water of Hiroshima Bay Japan. Oceanogr. Jpn., 13, 185-196, 2004.

Akhand, A., Chanda, A., Dutta, S., Manna, S., Sanyal, P., Hazra, S., Rao, K., and Dadhwal, V.: Dual character of Sundarban estuary as a source and sink of $\mathrm{CO}_{2}$ during summer: an investigation of spatial dynamics. Environ. Monit. Assess., 185, 6505-6515, 2013.

Arakaki, T., Fujimura, H., Hamdun, A.M., Okada, K., Kondo, H., Oomori, T., Tanahara, A., and Taira, H.: Simultaneous measurement of hydrogen peroxide and Fe species: (Fe(II) and $\mathrm{Fe}(\mathrm{tot})$ ) in Okinawa Island Seawater: impacts of red soil pollution. J. Oceanogr., 61, 561-568, 2005.

Arrigo, K. R., van Dijken, G., and Long, M.: Coastal Southern Ocean: A strong anthropogenic $\mathrm{CO}_{2}$ sink. Geophys. Res. Lett., 35, L21602, 2008.

Avery Jr, G. B., Cooper, W. J., Kieber, R. J., and Willey, J. D.: Hydrogen peroxide at the Bermuda Atlantic Time Series Station: Temporal variability of seawater hydrogen peroxide. Mar. Chem., 97, 236-244, 2005.

Baker, A. R., Weston, K., Kelly, S. D., Voss, M., Streu, P., and Cape, J. N.: Dry and wet deposition of nutrients from the tropical Atlantic atmosphere: Links to primary productivity and nitrogen fixation. Deep Sea Res. Part I, 54, 1704-1720, 2007.

Balch, W., Gordon, H. R., Bowler, B., Drapeau, D., and Booth, E.: Calcium carbonate measurements in the surface global ocean based on Moderate-Resolution Imaging Spectroradiometer data. J. Geophys. Res., 110, C(7), 2005.

Bates, N. R.: Seasonal variability of the effect of coral reefs on seawater $\mathrm{CO} 2$ and air-sea $\mathrm{CO} 2$ exchange. Limnol. Oceanogr., 47, 43-52, 2002.

Bates, N. R.: Air-sea $\mathrm{CO}_{2}$ fluxes and the continental shelf pump of carbon in the Chukchi Sea adjacent to the Arctic Ocean. J. Geophys. Res., 111, C10013, 2006.

Bates, N. R., and Peters, A. J.: The contribution of atmospheric acid deposition to ocean acidification in the subtropical North Atlantic Ocean. Mar. Chem., 107, 547-558, 2007.

Bauer, J. E., and Cai, W.-J., Raymond, P.A., Bianchi, T. S., Hopkinson, C. S., Regnier, P. A.: The changing carbon cycle of the coastal ocean. Nature, 504, 61-70, 2013.

Behrenfeld, M. J., Marañón, E., Siegel, D. A., and Hooker, S. B.: Photoacclimation and nutrient-based model of light-saturated photosynthesis for quantifying oceanic primary production. Mar. Ecol. Prog. Ser., 228, 103-117, 2002.

Biswas, H., Mukhopadhyay, S., De, T., Sen, S., and Jana, T.: Biogenic controls on the air-water carbon dioxide exchange in the Sundarban mangrove environment, northeast coast of Bay of Bengal, India. Limnol. Oceanogr., 49, 95-101, 2004.

Blagodatskaya, E., Blagodatsky, S., Dorodnikov, M., and Kuzyakov, Y.: Elevated atmospheric $\mathrm{CO}_{2}$ increases microbial growth rates in soil: results of three $\mathrm{CO} 2$ enrichment experiments. Glob. Change Biol., 16, 836-848, 2010.

Booth, J. A. T., McPhee-Shaw, E. E., Chua, P., Kingsley, E., Denny, M., Phillips, R., Bograd, S. J., Zeidberg, L. D., and Gilly, W. F.: Natural intrusions of hypoxic, low pH water into nearshore marine environments on the California coast. Cont. Shelf Res., 45, 108-115, 2012.

Borges, A.: Do we have enough pieces of the jigsaw to integrate $\mathrm{CO}_{2}$ fluxes in the coastal ocean? Estuaries, 28, 3-27, 2005. 
Borges, A., and Frankignoulle, M.:1999) Daily and seasonal variations of the partial pressure of $\mathrm{CO}_{2}$ in surface seawater along Belgian and southern Dutch coastal areas. J. Mar. Syst., 19, 251-266, 1999.

Borges, A., and Gypens, N.: Carbonate chemistry in the coastal zone responds more strongly to eutrophication than to ocean acidification. Limnol. Oceanogr., 55, 346-353, 2010.

Borges, A. V., Delille, B., and Frankignoulle, M.: Budgeting sinks and sources of $\mathrm{CO}_{2}$ in the coastal ocean: Diversity of ecosystems counts. Geophys. Res. Lett., 32, L14601, 2005.

Borges, A. V., and Frankignoulle, M.: Short-term variations of the partial pressure of $\mathrm{CO}_{2}$ in surface waters of the Galician upwelling system. Prog. Oceanogr., 51, 283-302, 2001.

Borges, A. V., and Frankignoulle, M.: Distribution and air-water exchange of carbon dioxide in the Scheldt plume off the Belgian coast. Biogeochemistry, 59, 41-67, 2002.

Borges, A. V., and Frankignoulle, M.: Distribution of surface carbon dioxide and air-sea exchange in the English Channel and adjacent areas. J. Geophys. Res., 108, 3140, 2003.

Byrne, R. H., Mecking, S., Feely, R. A., and Liu, X.: Direct observations of basin-wide acidification of the North Pacific Ocean. Geophys. Res. Lett., 37, L02601, 2010.

Cai, W.-J., Chen, L., Chen, B., Gao, Z., Lee, S.H., Chen, J., Pierrot, D., Sullivan, K., Wang, Y., Hu, X., Huang, W.-J., Zhang, Y., Xu, S., Murata, A., Grebmeier, J. M., Jones, E. P., and Zhang, H.: Decrease in the $\mathrm{CO}_{2}$ uptake capacity in an ice-free Arctic Ocean basin. Science 329, 556-559, 2010.

Cai, W. J., Dai, M., and Wang, Y.: Air-sea exchange of carbon dioxide in ocean margins: A province-based synthesis. Geophys. Res. Lett. 33, 2006.

Cai, W. J., Hu, X., Huang, W. J., Murrell, M. C., Lehrter, J. C., Lohrenz, S. E., Chou, W. C., Zhai, W., Hollibaugh, J. T., and Wang, Y.: Acidification of subsurface coastal waters enhanced by eutrophication. Nature Geosci., 4, 766-770, 2011.

Chen, C.-T. A., and Borges, A. V.: Reconciling opposing views on carbon cycling in the coastal ocean: Continental shelves as sinks and near-shore ecosystems as sources of atmospheric $\mathrm{CO}_{2}$. Deep Sea Res. Part II, 56, 578-590, 2009.

Chen, C. T. A., and Wang, S. L.: Carbon, alkalinity and nutrient budgets on the East China Sea continental shelf. J. Geophys. Res., 104, 20675-20686, 1999.

Chierici, M., Fransson, A., Turner, D. R., Pakhomov, E. A., and Froneman, P. W.: Variability in pH, fCO2, oxygen and flux of $\mathrm{CO} 2$ in the surface water along a transect in the Atlantic sector of the Southern Ocean. Deep Sea Res. Part II, 51, 2773-2787, 2004.

Clark, C. D., De Bruyn, W. J., Hirsch, C. M., and Jakubowski, S. D.: Hydrogen peroxide measurements in recreational marine bathing waters in Southern California, USA. Water Res. 44, 2203-2210, 2010.

Copin-Montégut, C., Bégovic, M., and Merlivat, L.: Variability of the partial pressure of $\mathrm{CO}_{2}$ on diel to annual time scales in the Northwestern Mediterranean Sea. Mar. Chem., 85, 169-189, 2004.

Corbière, A., Metzl, N., Reverdin, G., Brunet, C., and Takahashi, T.: Interannual and decadal variability of the oceanic carbon sink in the North Atlantic subpolar gyre. Tellus B, 59, 168-178, 2007.

Cyronak, T., Santos, I. R., McMahon, A., and Eyre, B. D.: Carbon cycling hysteresis in permeable carbonate sands over a diel cycle: Implications for ocean acidification. Limnol. Oceanogr., 58, 131143, 2013.

Dai, M., Guo, X., Zhai, W., Yuan, L., Wang, B., Wang, L., Cai, P., Tang, T., and Cai, W.-J.: Oxygen depletion in the upper reach of the Pearl River estuary during a winter drought. Mar. Chem., 102, 159$169,2006$.

Dai, M., Lu, Z., Zhai, W., Chen, B., Cao, Z., Zhou, K., Cai, W.-J., and Chen, C.-T. A.: Diurnal variations of surface seawater pCO:2) in contrasting coastal environments. Limnol. Oceanogr., 54, 735-745, 2009.

Dai, M., Zhai, W., Cai, W.-J., Callahan, J., Huang, B., Shang, S., Huang, T., Li, X., Lu, Z., and Chen, W.: Effects of an estuarine plume-associated bloom on the carbonate system in the lower reaches of the Pearl River estuary and the coastal zone of the northern South China Sea. Cont. Shelf Res., 28, 1416$1423,2008$.

Davidson, E. A., and Janssens, I. A.: Temperature sensitivity of soil carbon decomposition and feedbacks to climate change. Nature, 440, 165-173, 2006.

DeGrandpre, M., Hammar, T., and Wirick, C.: Short-term $\mathrm{pCO}_{2}$ and $\mathrm{O}_{2}$ dynamics in California coastal waters. Deep-Sea Res. Part II, 45, 1557-1575, 1998.

DeGrandpre, M., Olbu, G., Beatty, C., and Hammar, T.: Air-sea $\mathrm{CO}_{2}$ fluxes on the US Middle Atlantic Bight. Deep Sea Res. Part II, 49, 4355-4367, 2002. 
Delille, B., Delille, D., Fiala, M., Prevost, C., and Frankignoulle, M.: Seasonal changes of $\mathrm{pCO}_{2}$ over a subantarctic Macrocystis kelp bed. Polar Biol., 23, 706-716, 2000.

Doney, S. C., Mahowald, N., Lima, I., Feely, R. A., Mackenzie, F. T., Lamarque, J. F., and Rasch, P. J.: Impact of anthropogenic atmospheric nitrogen and sulfur deposition on ocean acidification and the inorganic carbon system. Proc. Nat. Aca. Sci., 104, 14580-14585, 2007.

Dore, J. E., Lukas, R., Sadler, D. W., Church, M. J., and Karl, D. M.: Physical and biogeochemical modulation of ocean acidification in the central North Pacific. Proc. Nat. Aca. Sci., 106, 12235-12240, 2009.

Dorodnikov M, K.Y., Fangmeier A, and Wiesenberg G. L. B.: C and N in soil organic matter density fractions under elevated atmospheric CO2: turnover vs stabilization. Soil Biol. Biochem., 43, 579-589, 2011.

Engel, A., Borchard, C., Piontek, J., Schulz, K. G., Riebesell, U., and Bellerby, R.: $\mathrm{CO}_{2}$ increases ${ }^{14} \mathrm{C}-$ primary production in an Arctic plankton community. Biogeosciences, 9, 1290-1308, doi:10.5194/bg10-1291-2013, 2013.

Fagan, K. E., and Mackenzie, F. T.: Air-sea $\mathrm{CO}_{2}$ exchange in a subtropical estuarine-coral reef system, Kaneohe Bay, Oahu, Hawaii. Mar. Chem., 106, 174-191, 2007.

Feely, R. A., Alin, S. R., Newton, J., Sabine, C.L., Warner, M., Devol, A., Krembs, C., and Maloy, C.: The combined effects of ocean acidification, mixing, and respiration on $\mathrm{pH}$ and carbonate saturation in an urbanized estuary. Estuar. Coast. Shelf Sci., 88, 442-449, 2010.

Feng, Y., Hare, C. E., Leblanc, K., Rose, J. M., Zhang, Y., DiTullio, G. R., Lee, P., Wilhelm, S., Rowe, J. M., and Sun, J.: The Effects of Increased $\mathrm{pCO}_{2}$ and Temperature on the North Atlantic Spring Bloom: I. The Phytoplankton Community and Biogeochemical Response. Mar. Ecol. Prog. Ser., 388, 13-25, 2009.

Findlay, H. S., Hennige, S. J., Wicks, L. C., Navas, J. M., Woodward, E. M. S., and Roberts, J. M.: Finescale nutrient and carbonate system dynamics around cold-water coral reefs in the northeast Atlantic. Sci. Rep., 4, 3671, 2014.

Flewelling, L. J., Naar, J. P., Abbott, J. P., Baden, D. G., Barros, N. B., Bossart, G. D., Bottein, M.-Y. D., Hammond, D. G., Haubold, E. M., and Heil, C. A.: Brevetoxicosis: Red tides and marine mammal mortalities. Nature, 435, 755-756, 2005.

Frankignoulle, M., and Borges, A. V.: European continental shelf as a significant sink for atmospheric carbon dioxide. Glob. Biogeochem. Cyc., 15, 569-576, 2001.

Frankignoulle, M., Bourge, I., Canon, C., and Dauby, P.: Distribution of surface seawater partial C02 pressure in the English Channel and in the Southern Bight of the North Sea. Cont. Shelf Res., 16, 381395, 1996.

Fransson, A., Chierici, M., and Anderson, L. G.: Diurnal variability in the oceanic carbon dioxide system and oxygen in the Southern Ocean surface water. Deep Sea Res. Part II, 51, 2827-2839, 2004.

Fu, P., Mostofa, K. M. G., Wu, F., Liu, C.-Q., Li, W., Liao, H., Wang, L., Wang, J., and Mei, Y.: Excitation-emission matrix characterization of dissolved organic matter sources in two eutrophic lakes:Southwestern China Plateau). Geochem. J., 44, 99, 2010.

Gagliano, M., McCormick, M. I., Moore, J. A., and Depczynski, M.: The basics of acidification: baseline variability of $\mathrm{pH}$ on Australian coral reefs. Mar. Biol., 157, 1849-1856, 2010.

Gago, J., Gilcoto, M., Pérez, F. F., and Rios, A.: Short-term variability off $\mathrm{CO}_{2}$ in seawater and air-sea $\mathrm{CO}_{2}$ fluxes in a coastal upwelling system (Ría de Vigo, NW Spain). Mar. Chem., 80, 247-264, 2003.

Gattuso, J.-P., Frankignoulle, M., and Smith, S. V.: Measurement of community metabolism and significance in the coral reef $\mathrm{CO}_{2}$ source-sink debate. Proc. Nat. Aca. Sci., 96, 13017-13022, 1999.

Gattuso, J.-P., Frankignoulle, M., and Wollast, R.: Carbon and carbonate metabolism in coastal aquatic ecosystems. Ann. Rev. Ecol. Syst., 29, 405-434, 1998.

Gattuso, J. P., Payri, C. E., Pichon, M., Delesalle, B., and Frankignoulle, M.: Primary production, calcification, and air-sea $\mathrm{CO}_{2}$ fluxes of a macroalgal-dominated coral reef community:Moorea, French Polynesia). J. Phycol., 33, 729-738, 1997.

González-Dávila, M., Santana-Casiano, J. M., Rueda, M.-J., Llinás, O., and González-Dávila, E.-F.: Seasonal and interannual variability of sea-surface carbon dioxide species at the European Station for Time Series in the Ocean at the Canary Islands:ESTOC) between 1996 and 2000. Glob. Biogeochem. Cyc., 17, 1076, 2003.

Goyet, C., and Peltzer, E. T.: Variation of $\mathrm{CO}_{2}$ partial pressure in surface seawater in the equatorial Pacific Ocean. Deep Sea Res. Part I, 44, 1611-1625, 1997. 
Graven, H. D., Keeling, R. F., Piper, S. C., Patra, P. K., Stephens, B. B., Wofsy, S. C., Welp, L. R., Sweeney, C., Tans, P. P., Kelley, J. J., Daube, B. C., Kort, E. A., Santoni, G. W., and Bent, J. D.: Enhanced seasonal exchange of $\mathrm{CO}_{2}$ by northern ecosystems since 1960. Science, 341: 1085-1089, 2013.

Gruber, N., Keeling, C. D., and Bates, N. R.: Interannual variability in the North Atlantic Ocean carbon sink. Science, 298, 2374-2378, 2002.

Hall-Spencer, J. M., Rodolfo-Metalpa, R., Martin, S., Ransome, E., Fine, M., Turner, S. M., Rowley, S. J., Tedesco, D., and Buia, M.-C.: Volcanic carbon dioxide vents show ecosystem effects of ocean acidification. Nature, 454, 96-99, 2008.

Haroon, M. F., Hu, S., Shi, Y., Imelfort, M., Keller, J., Hugenholtz, P., Yuan, Z., and Tyson, G. W.: Anaerobic oxidation of methane coupled to nitrate reduction in a novel archaeal lineage. Nature, 500, 567-570, 2013.

Hein, M., and Sand-Jensen, K.: $\mathrm{CO}_{2}$ increases oceanic primary production. Nature, 388, 526-527, 1997.

Herut, B., Shoham-Frider, E., Kress, N., Fiedler, U., and Angel, D. L.: Hydrogen peroxide production rates in clean and polluted coastal marine waters of the Mediterranean, Red and Baltic Seas. Mar. Pollut. Bull., 36, 994-1003, 1998.

Hofmann, G. E., Smith, J. E., Johnson, K. S., Send, U., Levin, L. A., Micheli, F., Paytan, A., Price, N. N., Peterson, B., and Takeshita, Y.: High-frequency dynamics of ocean pH: a multi-ecosystem comparison. PloS one 6, e28983, 2011.

Huesemann, M. H., Skillman, A. D., and Crecelius, E. A.: The inhibition of marine nitrification by ocean disposal of carbon dioxide. Mar. Pollut. Bull., 44, 142-148, 2002.

Hutchins, D. A., Fu, F.-X., Webb, E. A., Walworth, N., and Tagliabue, A.:2013) Taxon-specific response of marine nitrogen fixers to elevated carbon dioxide concentrations. Nature Geosci., 6, 790-795, 2013.

Invers, O., Romero, J., and Pérez, M.: Effects of pH on seagrass photosynthesis: a laboratory and field assessment. Aquat. Bot., 59, 185-194, 1997.

Jiang, Z.-P., Huang, J.-C., Dai, M., Kao, S. J., Hydes, D. J., Chou, W.-C., and Jan, S.: Short-term dynamics of oxygen and carbon in productive nearshore shallow seawater systems off Taiwan: Observations and modeling. Limnol. Oceanogr., 56, 1832-1849, 2011.

Kayanne, H., Hata, H., Kudo, S., Yamano, H., Watanabe, A., Ikeda, Y., Nozaki, K., Kato, K., Negishi, A., and Saito, H.: Seasonal and bleaching-induced changes in coral reef metabolism and $\mathrm{CO}_{2}$ flux. Glob. Biogeochem. Cyc., 19, GB3015, 2005.

Keeling, R. F.: Comment on "The Ocean sink for anthropogenic $\mathrm{CO}_{2}$ ". Science 308, 1743c, 2005.

Kieber, R. J., Whitehead, R. F., Reid, S. N., Willey, J. D., and Seaton, P. J.: Chromophoric dissolved organic matter (CDOM) in rainwater, southeastern North Carolina, USA. J. Atmos. Chem., 54, 21-41, 2006.

Kieber, R. J., Williams, K., Willey, J. D., Skrabal, S., and Avery Jr, G. B.: Iron speciation in coastal rainwater: concentration and deposition to seawater. Mar. Chem., 73, 83-95, 2001.

Knorr, W., Prentice, I. C., House, J. I., and Holland, E. A.: Long-term sensitivity of soil carbon turnover to warming. Nature, 433, 298-301, 2005.

Kraines, S., Suzuki, Y., Yamada, K., and Komiyama, H.: Separating biological and physical changes in dissolved oxygen concentration in a coral reef. Limnol. Oceanogr., 41, 1790-1799, 1996.

Kuffner, I. B., Andersson, A. J., Jokiel, P. L., Rodgers, K. U. S., and Mackenzie, F. T.: Decreased abundance of crustose coralline algae due to ocean acidification. Nature Geosci. 1, 114-117, 2008.

Kuss, J., Nagel, K., and Schneider, B.: Evidence from the Baltic Sea for an enhanced $\mathrm{CO}_{2}$ air-sea transfer velocity. Tellus B, 56, 175-182, 2004.

Kuypers, M. M. M., Sliekers, A. O., Lavik, G., Schmid, M., Jorgensen, B. B., Kuenen, J. G., Sinninghe Damste, J. S., Strous, M., and Jetten, M. S. M.: Anaerobic ammonium oxidation by anammox bacteria in the Black Sea. Nature, 422, 608-611, 2003.

Laws, E. A., Falkowski, P. G., Smith, W. O., Ducklow, H., and McCarthy, J. J.: Temperature effects on export production in the open ocean. Glob. Biogeochem. Cyc., 14, 1231-1246, 2000.

Le Quéré, C., Raupach, M. R., Canadell, J. G., and Marland, G.: Trends in the sources and sinks of carbon dioxide. Nature Geosci., 2, 831-836, 2009.

Li, Q., Chen, L., Chen, F., Gao, T., Li, X., Liu, S., and Li, C.: Maixi River estuary to the Baihua Reservoir in the Maotiao River catchment: phytoplankton community and environmental factors. Chin. J. Oceanol. Limnol., 31, 290-299, 2013. 
Long, S.-X., Chen, C., Liu, Z.-W., and Ye, X.-Y.: Relationship between phytoplankton and environment factors in Lake Hongfeng. J. Environ. Biol., 34, 445-449, 2013.

Ma, X., and Green, S. A.: Photochemical transformation of dissolved organic carbon in Lake Superior-An in-situ experiment. J. Great Lakes Res., 30, 97-112, 2004.

Manzello, D. P.: Ocean acidification hot spots: Spatiotemporal dynamics of the seawater $\mathrm{CO}_{2}$ system of eastern Pacific coral reefs. Limnol. Oceanogr., 55, 239-248, 2010.

Martens-Habbena, W., Berube, P. M., Urakawa, H., de la Torre, J.R., and Stahl, D. A.: Ammonia oxidation kinetics determine niche separation of nitrifying Archaea and Bacteria. Nature, 461, 976-979, 2009.

Matson, P. G., Martz, T. R., and Hofmann, G. E.: High-frequency observations of pH under Antarctic sea ice in the southern Ross Sea. Antarct. Sci.,23, 607-613, 2011.

Menéndez, M., Martínez, M., and Comín, F. A.: A comparative study of the effect of pH and inorganic carbon resources on the photosynthesis of three floating macroalgae species of a Mediterranean coastal lagoon. J. Exp. Mar. Biol. Ecol., 256, 123-136, 2001.

Middelboe, A. L., and Hansen, P. J.: High pH in shallow-water macroalgal habitats. Mar. Ecol. Prog. Ser., 338, 107-117, 2007.

Mostofa, K. M. G., Liu, C.-Q., Vione, D., Gao, K., and Ogawa, H.: Sources, factors, mechanisms and possible solutions to pollutants in marine ecosystems. Environ. Pollut., 182, 461-478, 2013a.

Mostofa, K. M. G., Liu, C.-Q., Gao, K., Li, S., Vione, D., and Mottaleb, M. A.: Impacts of Global Warming on Biogeochemical Cycles in Natural Waters, in: Photobiogeochemistry of Organic Matter: Principles and Practices in Water Environments, edited by: Mostofa, K. M. G., Yoshioka, T., Mottaleb, M. A., and Vione, D., Springer, Berlin Heidelberg, 851-914, $2013 \mathrm{~b}$.

Muyzer, G., and Stams, A. J.: The ecology and biotechnology of sulphate-reducing bacteria. Nature Rev. Microbiol., 6, 441-454, 2008.

Nakamura, T., and Nakamori, T.: Estimation of photosynthesis and calcification rates at a fringing reef by accounting for diurnal variations and the zonation of coral reef communities on reef flat and slope: a case study for the Shiraho reef, Ishigaki Island, southwest Japan. Coral Reefs, 28, 229-250, 2009.

Nearing, M., Pruski, F., and O'neal, M.:2004) Expected climate change impacts on soil erosion rates: a review. J. Soil Water Conservat., 59, 43-50, 2004.

Nyenje, P., Foppen, J., Uhlenbrook, S., Kulabako, R., and Muwanga, A.: Eutrophication and nutrient release in urban areas of sub-Saharan Africa - a review. Sci. Total Environ., 408, 447-455, 2010.

Ohde, S., and van Woesik, R.: Carbon dioxide flux and metabolic processes of a coral reef, Okinawa. Bull. Mar. Sci., 65, 559-576, 1999.

Ohtaki, E., Yamashita, E., and Fujiwara, F.: Carbon dioxide in surface seawaters of the Seto Inland Sea, Japan. J. Oceanogr., 49, 295-303, 1993.

Paerl, H., and Fogel, M.: Isotopic characterization of atmospheric nitrogen inputs as sources of enhanced primary production in coastal Atlantic Ocean waters. Mar. Biol., 119, 635-645, 1994.

Pan, Y., Ni, B.-J., and Yuan, Z.: Modeling Electron Competition among Nitrogen Oxides Reduction and N2O Accumulation in Denitrification. Environ. Sci. Technol., 47, 11083-11091, 2013.

Pergent-Martini, C., Boudouresque, C. F., Pasqualini, V., and Pergent, G.: Impact of fish farming facilities on Posidonia oceanica meadows: A review. Mar. Ecol., 27, 310-319, 2006.

Porcal, P., Koprivnjak, J.-F., Molot, L. A., and Dillon, P. J.: Humic substances-part 7: the biogeochemistry of dissolved organic carbon and its interactions with climate change. Environ. Sci. Pollut. Res., 16, 714-726, 2009.

Price, N. N., Martz, T. R., Brainard, R. E., and Smith, J. E.: Diel variability in seawater pH relates to calcification and benthic community structure on coral reefs. PloS one 7, e43843, 2012.

Regnier, P., Friedlingstein, P., Ciais, P., Mackenzie, F. T., Gruber, N., Janssens, I. A., Laruelle, G. G., Lauerwald, R., Luyssaert, S., and Andersson, A. J.: Anthropogenic perturbation of the carbon fluxes from land to ocean. Nature Geosci. 6, 597-607, 2013

Sakugawa, H., Kaplan, I. R., and Shepard, L. S.: Measurements of $\mathrm{H}_{2} \mathrm{O}_{2}$, aldehydes and organic acids in Los Angeles rainwater: Their sources and deposition rates. Atmos. Environ., 27, 203-219, 1993.

Sakugawa, H., Takami, A., Kawai, H., Takeda, K., Fujiwara, K., and Hirata, S.: The Occurrence of Organic Peroxides in Seawater, in: Dynamics and characterization of marine organic matter, edited by: Handa, N., Tanoue, E., and Hama, T., Springer, Tokyo, 231-240, 2000.

Sakugawa H., Yamashita, T., and Fujiwara K.:1995) Global Fluxes of Carbon and Its Related Substances in the Coastal Sea-ocean-atmosphere System: Proceedings of the 1994 Sapporo IGBP Symposium, 14-17 November 1994, Hokkaido University, Sapporo Hokkaido, Japan. M \& J International. 
Santos, I. R., Glud, R. N., Maher, D., Erler, D., and Eyre, B. D.: Diel coral reef acidification driven by porewater advection in permeable carbonate sands, Heron Island, Great Barrier Reef. Geophys. Res. Lett., 38, L03604, 2011.

Schiettecatte, L.-S., Thomas, H., Bozec, Y., and Borges, A.: High temporal coverage of carbon dioxide measurements in the Southern Bight of the North Sea. Mar. Chem., 106, 161-173, 2007.

Schippers, P., Lürling, M., and Scheffer, M.: Increase of atmospheric $\mathrm{CO}_{2}$ promotes phytoplankton productivity. Ecol. Lett., 7, 446-451, 2004.

Schneider, B., Nausch, G., Nagel, K., and Wasmund, N.: The surface water $\mathrm{CO}_{2}$ budget for the Baltic Proper: a new way to determine nitrogen fixation. J. Mar. Syst., 42, 53-64, 2003.

Sekar, R., Mills, D. K., Remily, E. R., Voss, J. D., and Richardson, L. L.: Microbial communities in the surface mucopolysaccharide layer and the black band microbial mat of black band-diseased Siderastrea siderea. Appl. Environ. Microbial., 72, 5963-5973, 2006.

Semesi, I. S., Beer, S., and Björk, M.: Seagrass photosynthesis controls rates of calcification and photosynthesis of calcareous macroalgae in a tropical seagrass meadow. Mar. Ecol. Prog. Ser., 382, 41 47, 2009.

Shim, J., Kim, D., Kang, Y. C., Lee, J.H., Jang, S.-T., and Kim, C.-H.: Seasonal variations in $\mathrm{pCO}_{2}$ and its controlling factors in surface seawater of the northern East China Sea. Cont. Shelf Res., 27, 2623-2636, 2007.

Smith, V. H., Tilman, G. D., and Nekola, J. C.: Eutrophication: impacts of excess nutrient inputs on freshwater, marine, and terrestrial ecosystems. Environ. Pollut., 100, 179-196, 1999.

Sunda, W.G., and Cai, W.-J.: Eutrophication induced $\mathrm{CO}_{2}$-acidification of subsurface coastal waters: Interactive effects of temperature, salinity, and atmospheric $\mathrm{PCO}_{2}$. Environ. Sci. Technol., 46, 1065110659, 2012.

Suzuki, A., and Kawahata, H.: Partial pressure of carbon dioxide in coral reef lagoon waters: comparative study of atolls and barrier reefs in the Indo-Pacific Oceans. J. Oceanogr., 55, 731-745, 1999.

Sweeney, C.: The annual cycle of surface water $\mathrm{CO}_{2}$ and $\mathrm{O}_{2}$ in the Ross Sea: A model for gas exchange on the continental shelves of Antarctica. Antarct. Res. Ser., 78, 295-312, 2003.

Taguchi, F., and Fujiwara, T.: Carbon dioxide stored and acidified low oxygen bottom waters in coastal seas, Japan. Estuar. Coast. Shelf Sci., 86, 429-433, 2010.

Takahashi, T., Sutherland, S. C., Sweeney, C., Poisson, A., Metzl, N., Tilbrook, B., Bates, N., Wanninkhof, R., Feely, R.A., and Sabine, C.: Global sea-air $\mathrm{CO}_{2}$ flux based on climatological surface ocean $p \mathrm{CO}_{2}$, and seasonal biological and temperature effects. Deep Sea Res. Part II, 49, 1601-1622, 2002.

Takahashi, T., Sutherland, S. C., Wanninkhof, R., Sweeney, C., Feely, R. A., Chipman, D. W., Hales, B., Friederich, G., Chavez, F., and Sabine, C.: Climatological mean and decadal change in surface ocean $\mathrm{pCO}_{2}$, and net sea-air $\mathrm{CO}_{2}$ flux over the global oceans. Deep Sea Res. Part II, 56, 554-577, 2009.

Teira, E., Hernando-Morales, V., Martínez-García, S., Figueiras, F. G., Arbones, B., and Álvarez-Salgado, X. A.: Response of bacterial community structure and function to experimental rainwater additions in a coastal eutrophic embayment. Estuar. Coast. Shelf Sci., 119, 44-53, 2013.

Thomas, H., Bozec, Y., Elkalay, K., De Baar, H., Borges, A., and Schiettecatte, L.-S.: Controls of the surface water partial pressure of $\mathrm{CO}_{2}$ in the North Sea. Biogeosciences 2, 323-334, 17264189/bg/2005-2-323, 2005.

Thomas, H., Bozec, Y., Elkalay, K., and de Baar, H. J. W.: Enhanced open ocean storage of $\mathrm{CO}_{2}$ from shelf sea pumping. Science, 304, 1005-1008, 2004.

Thomas, H., Schiettecatte, L.-S., Suykens, K., Koné, Y., Shadwick, E., Prowe, A., Bozec, Y., de Baar, H. J., and Borges, A.: Enhanced ocean carbon storage from anaerobic alkalinity generation in coastal sediments. Biogeosciences, 6, 267-274, doi:10.5194/bg-6-267-2009, 2009.

Vázquez-Domínguez, E., Vaqué, D., and Gasol, J. M.: Ocean warming enhances respiration and carbon demand of coastal microbial plankton. Glob. Change Biol., 13, 1327-1334, 2007.

Vitousek, P. M., Aber, J. D., Howarth, R. W., Likens, G. E., Matson, P. A., Schindler, D. W., Schlesinger, W. H., and Tilman, D. G.: Human alteration of the global nitrogen cycle: sources and consequences. Ecol. Appl., 7, 737-750, 1997.

Wang, F., Wang, B., Liu, C.-Q., Wang, Y., Guan, J., Liu, X., and Yu, Y.: Carbon dioxide emission from surface water in cascade reservoirs-river system on the Maotiao River, southwest of China. Atmos. Environ., 45, 3827-3834, 2011.

Wang, S.-L., Arthur Chen, C.-T., Hong, G.-H., and Chung, C.-S.: Carbon dioxide and related parameters in the East China Sea. Cont. Shelf Res., 20, 525-544, 2000. 
Ward, B.B.: How Nitrogen Is Lost. Science, 341, 352-353, 2013.

Ware, J. R., Smith, S. V., and Reaka-Kudla, M. L.: Coral reefs: sources or sinks of atmospheric $\mathrm{CO}_{2}$ ? Coral Reefs, 11, 127-130, 1992.

Wesslander, K., Hall, P., Hjalmarsson, S., Lefevre, D., Omstedt, A., Rutgersson, A., Sahlée, E., and Tengberg, A.: Observed carbon dioxide and oxygen dynamics in a Baltic Sea coastal region. J. Mar. Syst., 86, 1-9, 2011. U.: Changes in biogenic carbon flow in response to sea surface warming. Proc. Nat. Aca. Sci., 106, 7067-7072, 2009.

Wolf, A. A., Drake, B. G., Erickson, J. E., and Megonigal, J. P.: An oxygen-mediated positive feedback between elevated carbon dioxide and soil organic matter decomposition in a simulated anaerobic wetland. Glob. Change Biol., 13, 2036-2044, 2007.

Xie, H., Zafiriou, O. C., Cai, W.-J., Zepp, R. G., and Wang, Y.: Photooxidation and its effects on the carboxyl content of dissolved organic matter in two coastal rivers in the southeastern United States. Environ. Sci. Technol., 38, 4113-4119, 2004.

Yates, K. K., Dufore, C., Smiley, N., Jackson, C., and Halley, R. B.: Diurnal variation of oxygen and carbonate system parameters in Tampa Bay and Florida Bay. Mar. Chem., 104, 110-124, 2007.

Yuan, J., and Shiller, A. M.: The distribution of hydrogen peroxide in the southern and central Atlantic ocean. Deep Sea Res. Part II, 48, 2947-2970, 2001.

Zeebe, R. E., and Wolf-Gladrow, D.: $\mathrm{CO}_{2}$ in seawater: Equilibrium, kinetics, isotopes. Elsevier, 2001.

Zhai, W. D., and Dai, M.: On the seasonal variation of air-sea $\mathrm{CO}_{2}$ fluxes in the outer Changjiang:Yangtze River) Estuary, East China Sea. Mar. Chem., 117, 2-10, 2009.

Zhai, W. D., Dai, M., and Cai, W.-J.: Coupling of surface $\mathrm{pCO}_{2}$ and dissolved oxygen in the northern South China Sea: impacts of contrasting coastal processes. Biogeosciences, 6, 2589-2598, doi:10.5194/bg-62589-2009, 2009.

Zhai, W. D., Dai, M., Cai, W.-J., Wang, Y., and Hong, H.: The partial pressure of carbon dioxide and airsea fluxes in the northern South China Sea in spring, summer and autumn. Mar. Chem., 96, 87-97, 2005.

Zhai, W. D., Dai, M., and Guo, X.: Carbonate system and $\mathrm{CO}_{2}$ degassing fluxes in the inner estuary of Changjiang:Yangtze) River, China. Mar. Chem., 107, 342-356, 2007.

Zhai, W., Zhao, H., Zheng, N., and Xu, Y.: Coastal acidification in summer bottom oxygen-depleted waters in northwestern-northern Bohai Sea from June to August in 2011. Chin. Sci. Bull. 57, 1062-1068, 2012.

Zhai, W. D., Dai, M. H., Chen, B. S., Guo, X. H., Li, Q., Shang, S. L., Zhang, C.Y ., Cai, W. J., and Wang, D. X.: Seasonal variations of air-sea $\mathrm{CO}_{2}$ fluxes in the largest tropical marginal sea (South China Sea) based on multiple-year underway measurements. Biogeosciences 10, 7775-7791, doi:10.5194/bg-107775-2013, 2013.

Zhai, W. D., Zheng, N., Huo, C., Xu, Y., Zhao, H. D., Li, Y. W., Zang, K. P., Wang, J. Y., and Xu, X. M.: Subsurface $\mathrm{pH}$ and carbonate saturation state of aragonite on the Chinese side of the North Yellow Sea: seasonal variations and controls. Biogeosciences, 11, 1103-1123, doi:10.5194/bg-11-1103-2014, 2014.

Zhang, C., Huang, H., Ye, C., Huang, L., Li, X., Lian, J., and Liu, S.: Diurnal and seasonal variations of carbonate system parameters on Luhuitou fringing reef, Sanya Bay, Hainan Island, South China Sea. Deep Sea Res. Part II, 96, 65-74, 2013.

Zhang, M., Wang, S., Wu, F., Yuan, X., and Zhang, Y.: Chemical compositions of wet precipitation and anthropogenic influences at a developing urban site in southeastern China. Atmos. Res., 84, 311-322, 2007.

Zou, L., Chen, H. T., and Zhang, J.: Experimental examination of the effects of atmospheric wet deposition on primary production in the Yellow Sea. J. Exp. Mar. Biol. Ecol., 249, 111-121, 2000. 


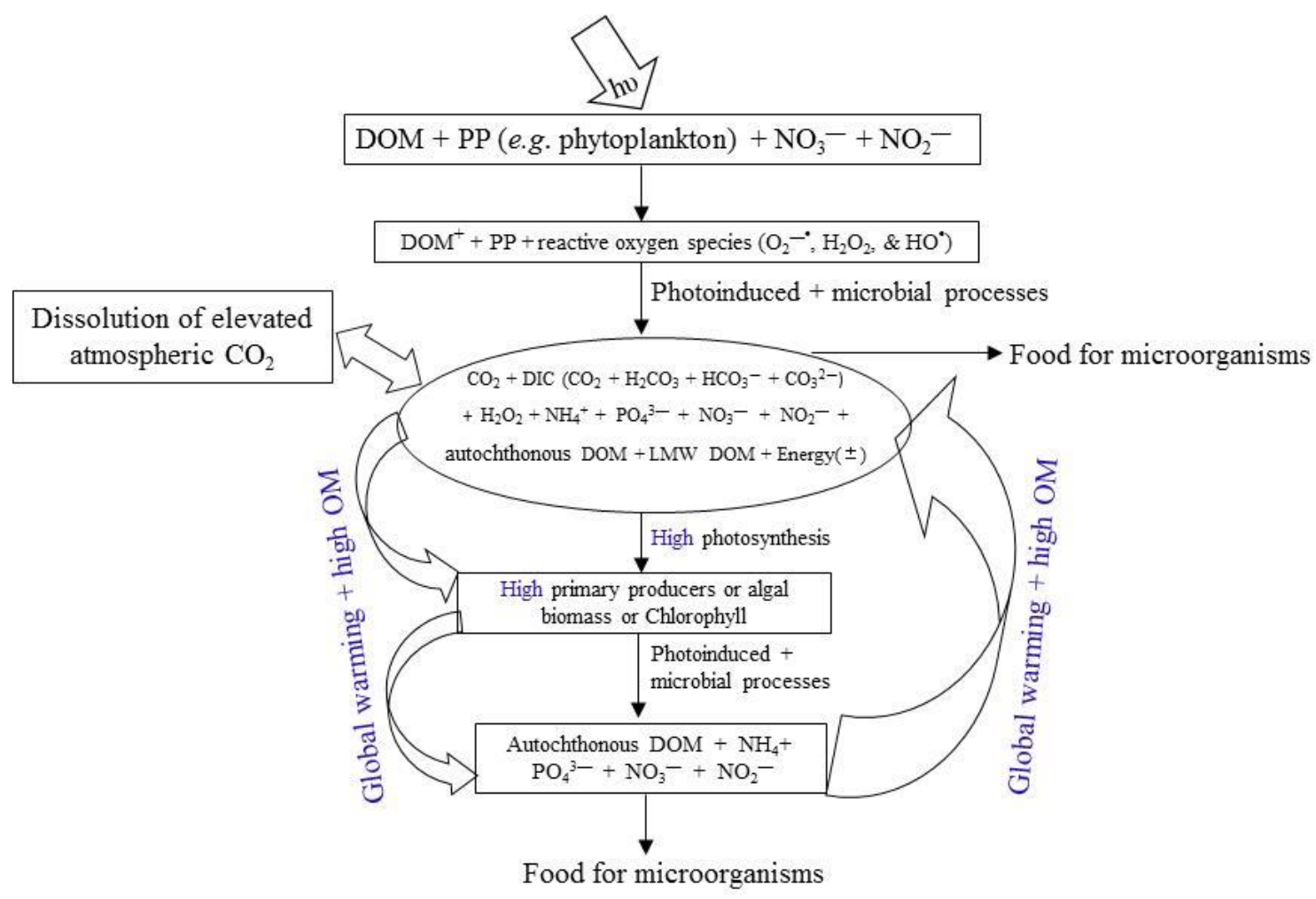

Figure S1. A conceptual schematic diagram about the response to global warming effects and high organic matter (OM) including DOM and PP, as well as the possible effects on the occurrence of harmful algal blooms in water. First, photoinduced transformation is the primary step for the generation of the oxidizing species $\left(\right.$ e.g. $\mathrm{H}_{2} \mathrm{O}_{2}$ and $\mathrm{HO}^{\circ}$ ) from DOM. Such processes, along with biological ones, can drive respiration/degradation of DOM and dead organisms, yielding a variety of intermediates and byproducts among which $\mathrm{CO}_{2}$, DIC, and nutrients $\left(\mathrm{NO}_{3}{ }^{-}, \mathrm{PO}_{4}{ }^{3-}\right)$. Second, such products can enhance photosynthesis with a subsequent increase of the PP (phytoplankton). Third, PP further induces photoinduced and microbial respiration that releases autochthonous DOM and nutrients. Fourth, autochthonous DOM and nutrients undergo photoinduced and microbial degradation that further yields $\mathrm{CO}_{2}$, DIC and again nutrients. Increased temperature following global warming and input of high $\mathrm{OM}$ in water can favor the occurrence of high photosynthesis for a longer period of time and, as a consequence, enhance primary production. This issue can lead to an increase of the worldwide 

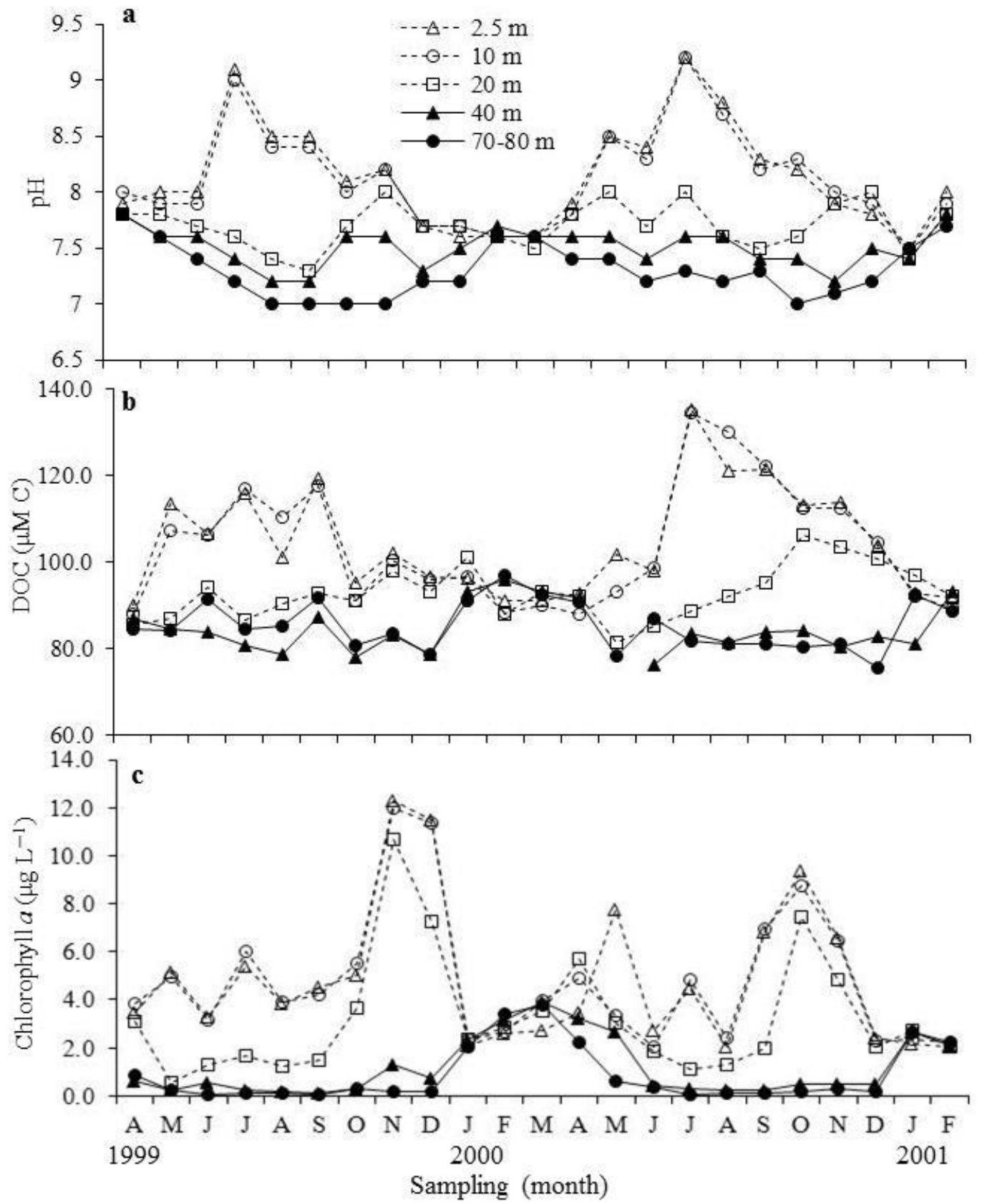

747 Figure S2. Monthly changes in $\mathrm{pH}$, dissolved organic carbon (DOC) and chlorophyll $a$ 748 (Chl $a)$ at different water depths $(2.5,10,20,40$ and 70-80 m) in Lake Biwa, the 11th 
749 largest lake in the world with surface area of approximately $674.8 \mathrm{~km}^{2}$. Samples were 750 collected monthly during the period of April 1999 to February 2001 at day-time from the 751 northern basin, where the maximum water depth is $104 \mathrm{~m}$ (Mostofa et al., 2005). The 752 values of $\mathrm{pH}$ and of the concentrations of DOC and $\mathrm{Chl} a$ gradually increased, reaching a 753 maximum on July (1999 and 2000) for pH, on September (1999) or July (2000) for DOC 754 and on November (1999) or October (2000) for Chl $a$.

755

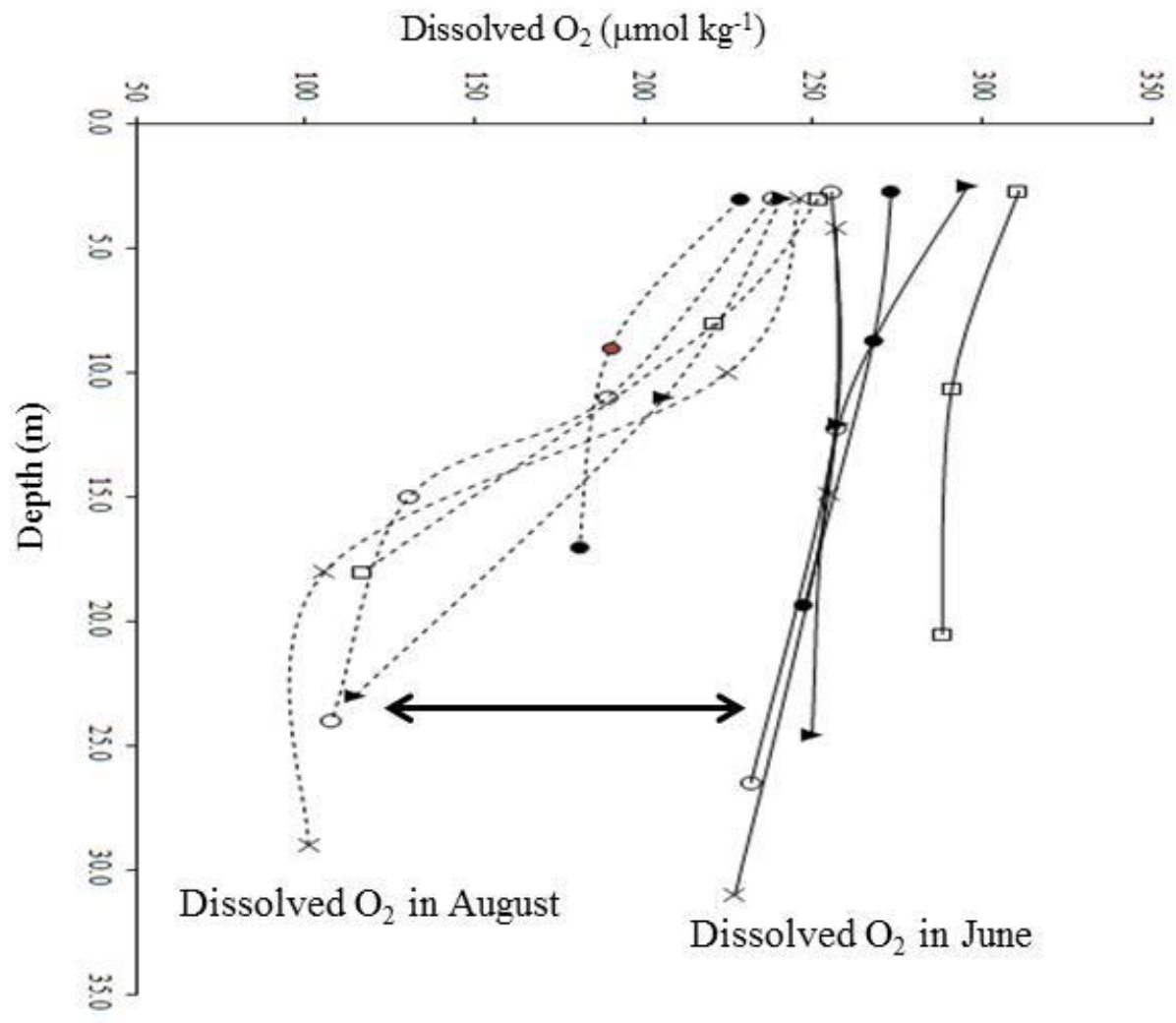

757

Figure S3. A substantial decline in dissolved $\mathrm{O}_{2}$ contents in August (dashed lines) compared to June (solid lines) in the seawater of the Yellow Sea. The same symbol indicates the same sampling site for the samples collected during June and August. 


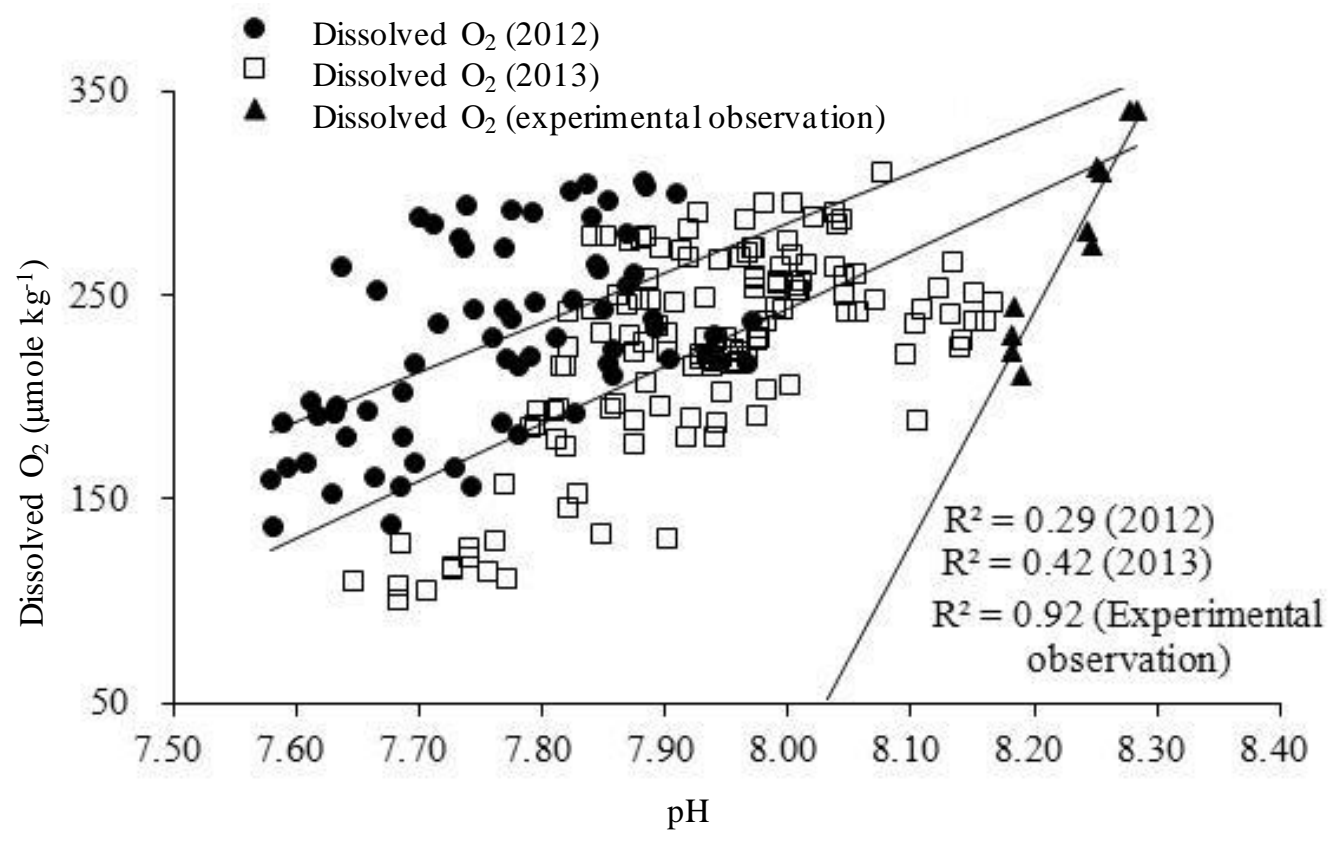

Figure S4. Relationship between $\mathrm{pH}$ and dissolved $\mathrm{O}_{2}$ for a variety of the subsurface seawaters collected from the Yellow Sea in 2012 and 2013. Experiments were carried out on July 2, 2013 using subsurface water collected at $37 \mathrm{~m}$ depth from the East China Sea (see the caption of Fig. 4 for a detailed description). 
785 
786 Table S1. Ranges of $\mathrm{pH}, \mathrm{PCO}_{2}$, DIC, chlorophyll $a(\mathrm{Chl} a)$, dissolved $\mathrm{O}_{2}$, hydrogen peroxide $\left(\mathrm{H}_{2} \mathrm{O}_{2}\right)$ and water temperature $(\mathrm{WT})$ in 787 world's oceans.

\begin{tabular}{|c|c|c|c|c|c|c|c|c|c|c|}
\hline \multirow[t]{2}{*}{ Sampling } & \multicolumn{2}{|c|}{$\mathrm{pH}$} & \multirow{2}{*}{$\begin{array}{l}\mathrm{PCO}_{2} \\
(\mu \mathrm{atm}) \\
\end{array}$} & \multirow{2}{*}{$\begin{array}{c}\text { DIC } \\
\left(\mu \mathrm{mol} \mathrm{kg}^{-1}\right) \\
\end{array}$} & \multirow{2}{*}{$\begin{array}{l}\mathrm{Chl} a \\
\left(\mu \mathrm{g} \mathrm{L}^{-1}\right)\end{array}$} & \multicolumn{2}{|c|}{ Dissolved $\mathrm{O}_{2}$} & \multirow{2}{*}{$\begin{array}{l}-\mathrm{H}_{2} \mathrm{O}_{2} \\
(\mathrm{nM})\end{array}$} & \multirow[t]{2}{*}{ WT } & \multirow[t]{2}{*}{ References } \\
\hline & $\begin{array}{c}\text { Surface water } \\
(0-20 \mathrm{~m})\end{array}$ & Anoxic zone & & & & Surface water & Anoxic zone & & & \\
\hline Okinawa Island Seawater (Taira Bay, November) & $8.02-8.79$ (diurnal) & - & & & & - & - & $40-160$ & $21-7-23.7$ & Arakaki et al, 2005 \\
\hline Okinawa Island Seawater (Taira Bay, January) & $8.16-8.25$ (diurnal) & - & & - & - & - & - & $40-100$ & $18.8-20.9$ & Arakaki et al., 2005 \\
\hline Okinawa Island Seawater (Sesoko Island, January) & $7.82-8.29$ (diurnal) & - & - & - & - & - & - & $30-110$ & $17.7-20.2$ & Arakaki et al, 2005 \\
\hline Nanwan Bay, south coast of Taiwan (5-13 June) & $8.04-8.24$ (diurnal) & - & $227-532$ & $1830-2050$ & $0.20-1.10$ & $2.62-5.74$ & - & - & 22.4-28.4 & Jiang et al, $2011^{*}$ \\
\hline Coastal seawater, Aodi, northeast of Taiwan (1-5 August) & 7.87-8.35 (diurnal) & - & $178-582$ & $1750-2090$ & $0.30-1.30$ & $2.70-6.56$ & - & - & $25.0-28.0$ & Jiang et al., 2011" \\
\hline Coastal seawater (Bay of Bengal, Stn 3) & $8.12-8.37$ (diurnal) & - & $153-373$ & - & $12.35 \pm 2.23$ & - & - & - & $28.50-31.70$ & Akhand et al, 2013 \\
\hline Marine bathing waters (Southern California, USA) & $\sim 7.37-8.18$ (diurnal) & - & - & - & - & - & - & $5-370$ & $18.6-22.5$ & Clark et al, $2010^{*}$ \\
\hline Inner shelf of southern Monterey Bay, California coast & 7.7-8.1 (diurnal) & - & & - & - & $2.0-4.6$ & - & - & $9.5-13.5$ & Booth et al, 2012* \\
\hline Tampa Bay & 7.95-8.24 (diurnal) & 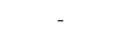 & $262-580$ & - & - & - & - & - & $26.2-28.7$ & Yates et al., 2007 \\
\hline Florida Bay & $8.17-8.39$ (diurnal) & - & $260-497$ & - & - & - & - & - & $23.8-27.3$ & Yates et al, 2007 \\
\hline Belgian coastal seawater (near Zeebrugge) & 8.314-8.358 (diurnal) & - & $190-214$ & - & $12.5-23.5$ & - & - & - & $9.74-10.15$ & Borges and Frankignoulle, $1999^{\circ}$ \\
\hline Seawater, Jarvis Island & 7.985-8.019 (diurnal) & - & - & - & - & - & - & - & - & Price et al, 2012 \\
\hline Great Barrier Reef, Lizard Island (subsurface: within $5 \mathrm{~cm}$ of the surface) & 7.93-8.23 (diurnal) & - & - & - & - & - & - & - & - & Gagliano et al, 2010 \\
\hline Great Barrier Reef, Lizard Island (Pocillopora damicornis) & 7.93-8.30 (diurnal) & - & - & - & - & - & - & - & - & Gagliano et al., 2010 \\
\hline Great Barrier Reef, Lizard Island (D. perspicillatus algal garden) & 7.95-8.25 (diurnal) & 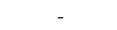 & - & - & 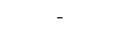 & - & - & - & - & Gagliano et al., 2010 \\
\hline Great Barrier Reef, Lizard Island (open sand: within $3 \mathrm{~cm}$ of the sand) & $7.80-8.24$ (diurnal) & - & - & - & - & - & - & - & - & Gagliano et al, 2010 \\
\hline Great Barrier Reef, Heron Island & 7.69-8.44 (diurnal) & - & - & - & - & $0.46-7.59$ & - & - & $22.2-32.0$ & Santos et al., 2011 \\
\hline Luhuitou fringing reef, Sanya Bay, South China Sea (winter) & 7.95-8.07 (diurnal) & - & $\sim 380-500$ & - & - & $\sim 5.0-8.0$ & - & - & $24.5 \pm 0.5$ & Zhang et al., 2013* \\
\hline Luhuitou fringing reef, Sanya Bay, South China Sea (spring) & 7.96-8.14 (diurnal) & - & $\sim 290-460$ & - & - & $\sim 5.5-8.0$ & - & - & $33.8 \pm 0.1$ & Zhang et al, $2013^{*}$ \\
\hline Luhuitou fringing reef, Sanya Bay, South China Sea (summer) & $\sim 7.86-8.07$ (diurnal) & - & $\sim 350-605$ & - & - & $\sim 3.5-7.2$ & - & - & $29.5 \pm 0.6$ & Zhang et al., 2013* \\
\hline Luhuitou fringing reef, Sanya Bay, South China Sea (autumn) & 7.94-8.18 (diurnal) & - & $\sim 245-495$ & - & - & $\sim 5.3-10.7$ & - & - & $26.3 \pm 1.0$ & Zhang et al., 2013" \\
\hline Seawater, Kingman Reef (site Palmyra Terrace North) & $7.926-8.031$ (diurnal) & 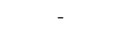 & - & - & - & - & - & - & - & Price et al, 2012 \\
\hline Seawater, Kingman Reef (site Palmyra Terrace South) & $7.901-8.017$ (diurnal) & - & - & - & - & - & - & - & - & Price et al, 2012 \\
\hline Seawater, Kingman Reef (site Palmyra Forereef North) & $7.944-8.007$ (diurnal) & - & - & - & ـ & - & - & - & - & Price et al, 2012 \\
\hline Seawater, Kingman Reef (site Palmyra Forereef South) & $7.979-8.007$ (diurnal) & - & - & - & - & - & - & - & - & Price et al, 2012 \\
\hline Seawater, Kingman Reef (site Kingman Reef) & $8.021-8.028$ (diurnal) & - & - & - & - & - & - & - & - & Price et al, 2012 \\
\hline Coral reef, Ishigaki Island, Japan & 7.9-8.4 (diurnal) & - & - & - & - & - & - & - & & Kayanne et al, 2005 \\
\hline Coral reef, Rukan-sho, Ishigaki Island, Japan (site 1, October) & $7.848-8.556$ (diurnal) & 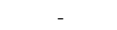 & $151-900$ & $1460-2103$ & - & $1.81-13.37$ & - & - & $26.4-30.2$ & Ohde and van Woesik, 1999 \\
\hline Coral reef, Rukan-sho, Ishigaki Island, Japan (site 1, September) & $7.951-8.688$ (diurnal) & - & $68-770$ & $1181-2095$ & - & - & - & - & $27.3-34.2$ & Ohde and van Woesik, 1999 \\
\hline Reef crest algal community, Ishigaki Island, Japan & 7.863-8.335 (diurnal) & - & $210-762$ & $1101-2090$ & - & - & - & - & $29.84-33.19$ & Nakamura and Nakamori, 2009 \\
\hline Branching acropora (coral) community, Ishigaki Island, Japan (site 4) & $8.030-8.289$ (diurnal) & - & $201-458$ & - & - & - & - & - & 29.0 & Nakamura and Nakamori, 2009 \\
\hline Branching acropora (coral) community, Ishigaki Island, Jap & $7.818-8.211$ (diurnal) & - & $271-770$ & - & - & - & - & - & $27.56-30.73$ & Nakamura and Nakamori, 2009 \\
\hline Branching acropora (coral) com & $7.801-8.197$ (diurnal) & - & $248-799$ & - & - & - & - & - & $27.87-30.62$ & Nakamura and Nakamori, 2009 \\
\hline Montipora stellata (coral) comn & 7.773-8.387 (diurnal) & - & $144-919$ & - & - & - & - & - & $28.39-33.18$ & Nakamura and Nakamori, 2009 \\
\hline Pocillopora acropora (coral) community, Ish & 7.974-8.099 (diurnal) & - & $410-569$ & - & - & - & - & - & $30.72-31.25$ & Nakamura and Nakamori, 2009 \\
\hline Pocillopora acropora (coral) community, Ishigaki Island, Japan (site 10) & 7.939-8.113 (diurnal) & - & $368-593$ & - & - & $=$ & - & - & $28.27-29.91$ & Nakamura and Nakamori, 2009 \\
\hline Seawater in the coral reef, Heron Island, Great Barrier Reef & $7.96-8.36$ (diel) & - & - & $1850-2230$ & - & $3.11-7.05$ & - & - & & Cyronak et al., 2013" \\
\hline va Reef, Gulf & $7.63-8.20$ (day) & - & 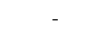 & & - & - & - & - & $28.8 \pm 0.19$ & Manzello, 2010 \\
\hline Uva Reef, Gulf of Chiriqu, Pacific Panamá (dry season) & $7.84-8.04$ (night) & & & & & & & & $28.4 \pm 0.30$ & Manzello, 2010 \\
\hline
\end{tabular}


$791 \quad$ Table S1 (continued)

\begin{tabular}{|c|c|c|c|c|c|c|c|c|c|c|}
\hline \multirow[t]{3}{*}{ Sampling } & \multicolumn{2}{|l|}{$\mathrm{pH}$} & \multirow{3}{*}{$\begin{array}{l}P^{P \mathrm{CO}_{2}} \\
\\
\text { (natm) }\end{array}$} & \multirow{3}{*}{$\begin{array}{c}\text { DIC } \\
\left(\mu \mathrm{mol} \mathrm{kg}^{-1}\right)\end{array}$} & \multirow{3}{*}{$\begin{array}{c}\mathrm{Chl} a \\
\left(\mu \mathrm{g} \mathrm{L}^{-1}\right)\end{array}$} & \multicolumn{2}{|c|}{ Dissolved $\mathrm{O}_{2}$} & \multirow[t]{2}{*}{$\mathrm{H}_{2} \mathrm{O}_{2}$} & \multirow[t]{3}{*}{ WT } & \multirow[t]{3}{*}{ References } \\
\hline & Surface water & Anoxic zone & & & & Surface water & Anoxic zone & & & \\
\hline & $(0-20 \mathrm{~m})$ & & & & & \multicolumn{2}{|c|}{$\left(\mathrm{mg} \mathrm{L}^{-1}\right)$} & $(\mathrm{nM})$ & & \\
\hline Uva Reef, Gulf of Chiriqu, Pacific Panamá (wet season) & $7.94-8.26$ (day) & - & - & & & 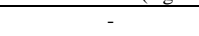 & - & 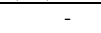 & $28.9 \pm 0.06$ & Manzello, 2010 \\
\hline Uva Reef, Gulf of Chiriqu, Pacific Panamá (wet season) & 7.86-8.01 (night) & - & - & - & - & - & - & - & $28.7 \pm 0.03$ & Manzello, 2010 \\
\hline Saboga Reef, Gulf of Panamá (dry season) & $7.95-8.08$ (day) & - & - & - & - & - & - & - & 21.0 & Manzello, 2010 \\
\hline Saboga Reef, Gulf of Panamá (wet season) & $7.95-8.23$ (day) & - & - & - & - & - & - & - & $28.6 \pm 0.11$ & Manzello, 2010 \\
\hline Saboga Reef, Gulf of Panamá (wet season) & $7.96-8.00$ (night) & - & - & - & - & - & - & - & 27.5 & Manzello, 2010 \\
\hline Reef, Galápagos, Eastern Pacific (cool) & $7.65-7.99$ (day) & - & - & - & - & - & - & - & 25.0 & Manzello, 2010 \\
\hline Reef, Galápagos, Eastern Pacific (warm) & $7.70-8.07$ (day) & - & - & - & - & - & - & - & 25.0 & Manzello, 2010 \\
\hline Fore reef (benthic), Palmyra $\left(5.86614^{\circ} \mathrm{N}, 162.1172^{\circ} \mathrm{W}\right)$ & $7.915-8.035$ (30 days) & - & - & - & - & - & - & - & - & Hofmann et al, 2011 \\
\hline Reef terrace (benthic), Palmyra $\left(5.884^{\circ} \mathrm{N}, 162.1218^{\circ} \mathrm{W}\right)$ & $7.851-8.104$ (30 days) & - & - & - & - & - & - & - & - & Hofmann et al., 2011 \\
\hline Fringing reef (benthic), Moorea $\left(17.4803^{\circ} \mathrm{S}, 149.7989^{\circ} \mathrm{W}\right)$ & $8.017-8.118$ (30 days) & - & - & - & - & - & - & - & - & Hofmann et al., 2011 \\
\hline Kingman Reef (benthic), Tropical Central Pacific, Open Ocean & $8.009-8.034$ (30 days) & - & - & - & - & - & - & - & - & Hofmann et al, 2011 \\
\hline SBC Mohawk Reef (benthic), Kelp $\left(34.3943^{\circ} \mathrm{N}, 119.73^{\circ} \mathrm{W}\right)$ & $7.700-8.244$ ( 30 days) & - & - & - & - & - & - & - & - & Hofmann et al, 2011 \\
\hline Coral Reef Lagoon seawater (The Indo-Pacific Oceans) & $8.264-8.350$ & - & $292-370$ & - & - & - & - & - & $28.6-30.0$ & Suzuki and Kawahata, 1999 \\
\hline Coral reef (mesocosm), Moku O Loe, Kaneohe Bay, Hawaii & $7.55-8.08$ & - & $500-1950$ & - & - & - & - & - & - & Kuffiner et al, 2008 \\
\hline Seagrass community, Chwaka Bay (Zanzibar, Tanzania) & 7.9->8.9 (diurnal) & - & - & - & - & - & - & - & $\sim 27.0-33.0$ & Semesi et al., 2009 \\
\hline Seagrass community, Ishigaki Island, Japan (site 1) & 7.763-8.547 (diurnal) & - & $111-1085$ & - & - & - & - & - & $30.87-34.32$ & Nakamura and Nakamori, 2009 \\
\hline Seagrass community, Ishigaki Island, Japan (site 2) & 7.894-8.353 (diurnal) & - & $204-671$ & - & - & - & - & - & $27.99-33.22$ & Nakamura and Nakamori, 2009 \\
\hline Seagrass community (C. nodosa), Alfacs Bay, Mediterranean $(1 \mathrm{~m})$ & $8.11-8.59$ (diurnal) & - & - & - & - & - & - & - & - & Invers et al, 1997 \\
\hline Seagrass community $(P$. oceanica $)$, Alfacs Bay, Mediterranean $(1 \mathrm{~m})$ & $8.15-8.45$ (diurnal) & - & - & - & - & - & - & - & - & Invers et al., 1997 \\
\hline Seagrass community $(P$. oceanica $)$, Alfacs Bay, Mediterranean $(4 \mathrm{~m})$ & $8.17-8.34$ (diurnal) & - & - & - & - & - & - & - & - & Invers et al, 1997 \\
\hline Benthos community, Ishigaki Island, Japan (site 2) & 7.963-8.154 (diurnal) & - & $318-540$ & - & - & - & - & - & $28.66-31.61$ & Nakamura and Nakamori, 2009 \\
\hline Macroalgal Kelp bed (inside), Morbihan Bay, Southern Ocean & 8.07-9.11 (diurnal) & - & - & - & - & - & - & - & $0.7-15.3$ & Delille et al., 2000 \\
\hline Macroalgal Kelp bed (outside), Morbihan Bay, Southern Ocean & 7.94-8.46 (diurnal) & - & - & - & - & - & - & - & $0.7-8.5$ & Delille et al., 2000 \\
\hline Macroalgae (outside), macroalgal mats, Mediterranean coastal lagoon & $8.3-9.0$ (diurnal) & - & - & $2500-3000$ & - & - & - & - & - & Menéndez et al, 2001 \\
\hline Macroalgae (inside), macroalgal mats, Mediterranean coastal lagoon & 8.4-9.6 (diurnal) & - & - & $2500-3000$ & - & - & - & - & - & Menéndez et al, 2001 \\
\hline Macroalgal habitats, inshore Danish waters $(0.2 \mathrm{~m})$ & 7.5-9.1 (diurnal) & - & - & - & - & - & - & - & - & Middelboe and Hansen, $2007^{*}$ \\
\hline Macroalgal habitats, inshore Danish waters $(0.4 \mathrm{~m})$ & 7.8-9.0 (diurnal) & - & - & - & - & - & - & - & - & Middelboe and Hansen, 2007* \\
\hline Macroalgal habitats, inshore Danish waters $(0.6 \mathrm{~m})$ & $8.0-8.9$ (diurnal) & - & - & - & - & - & - & - & - & Middelboe and Hansen, 2007* \\
\hline Macroalgal Kelp bed, La Jolla (pelagic) & $7.970-8.229$ (30 days) & - & - & - & - & - & - & - & - & Hofmann et al., 2011 \\
\hline Southern Ocean surface water (Sta. SIE1) & 8.13-8.17 (diurnal) & - & $\sim 280-305$ & - & - & - & - & - & $\sim(-0.05)-(-0.25)$ & Fransson et al, $2004^{*}$ \\
\hline Southern Ross Sea under Antarctic sea ice (site: Cape Evans) & $8.039-8.134$ (diel, $15 \mathrm{~m}$ ) & - & - & - & - & - & - & - & - & Matson et al, 2011 \\
\hline Temperate Eastern Pacific (CCE1), Open Ocean & $8.059-8.082$ (30 days) & - & - & - & - & - & - & - & - & Hofmann et al., 2011 \\
\hline Polar seawater (benthic), Cindercones, Antarctic Ocean & $8.039-8.134$ (30 days) & - & - & - & - & - & - & - & - & Hofmann et al., 2011 \\
\hline Polar seawater (benthic), Cape Evans, Antarctic Ocean & $8.002-8.050$ (30 days) & - & - & - & - & - & - & - & - & Hofmann et al, 2011 \\
\hline Upper Reach of the Pearl River Estuary (South China Sea) & $6.98-7.75$ & - & $\leq 7460$ & $1900-2740$ & - & $0.25-3.61$ & - & - & $\sim 14.5-16.8$ & Dai et al, 2006 \\
\hline Outer estuary of Yangtze River (East China Sea) & $7.76-8.03$ (spring) & - & $560-800$ & $1575-1840$ & - & - & - & - & $14.6-15.7$ & Zhai et al., 2007 \\
\hline Outer estuary of Yangtze River (East China Sea) & 7.92-8.04 (winter) & . & $316-477$ & 1935-1995 & - & - & - & 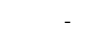 & $7.1-15.5$ & Zhai et al, 2007 \\
\hline Bohai and Liaodong Bay $(0$ to $\sim 15-20 \mathrm{~m})$ & 7.90-8.12 (June) & $\sim 7.82-8.04$ & - & - & - & $\sim 7.05-10.16$ & $\sim 7.21-9.51$ & - & $\sim 13.0-18.5^{*}$ & Zhai et al, 2012 \\
\hline Bohai and Liaodong Bay ( 0 to $\sim 15-20 \mathrm{~m}$ ) & 7.86-8.17 (August) & $\sim 7.64-7.96$ & - & - & - & $\sim 7.21-9.18$ & $\sim 3.28-7.38$ & - & $\sim 19.0-27.0^{*}$ & Zhai et al., 2012 \\
\hline Yellow Sea: Northern side & 7.67-7.92 (winter) & $\sim 7.67-7.75$ & - & - & - & $\sim 9.90-(6 \mathrm{~m})$ & - & - & $(-1.45)-6.74$ & Zhai et al, 2014 \\
\hline Yellow Sea: Northern side & $7.85-8.11$ (spring) & $\sim 7.69-7.78$ & - & - & - & - & - & - & $\sim 4.50-13.22$ & Zhai et al., 2014 \\
\hline Yellow Sea: Northern side & $7.86-8.14$ (summer) & $\sim 7.62-7.92$ & - & - & - & 7.44-9.54 (13-19 m) & - & - & $\sim 5.00-24.83$ & Zhai et al., 2014 \\
\hline Yellow Sea: Northern side & $7.76-8.11$ (autumn) & $7.53-7.60$ & - & 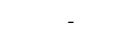 & - & $6.82(19 \mathrm{~m})$ & - & 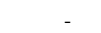 & $\sim 7.50-18.37$ & Zhai et al., 2014 \\
\hline East China Sea & $8.04-8.22$ & 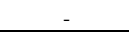 & - & $1980-2220$ & - & 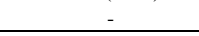 & - & - & $\sim 12-25$ & Wang et al, 2000 \\
\hline
\end{tabular}


794 Table S1 (continued)

\begin{tabular}{|c|c|c|c|c|c|c|c|c|c|c|}
\hline \multirow[t]{2}{*}{ Sampling } & \multicolumn{2}{|c|}{$\mathrm{pH}$} & \multirow{2}{*}{$\begin{array}{l}\mathrm{PCO}_{2} \\
\text { (ratm) }\end{array}$} & \multirow{2}{*}{$\begin{array}{c}\text { DIC } \\
\left(\mu \mathrm{mol} \mathrm{kg}^{-1}\right) \\
\end{array}$} & \multirow{2}{*}{$\begin{array}{c}\text { Chl } a \\
\left(\mu \mathrm{gL}^{-1}\right)\end{array}$} & \multicolumn{2}{|l|}{ Dissolved $\mathrm{O}_{2}$} & \multirow[t]{2}{*}{$\mathrm{H}_{2} \mathrm{O}_{2}$} & \multirow[t]{2}{*}{ WT } & \multirow[t]{2}{*}{ References } \\
\hline & $\begin{array}{c}\text { Surface water } \\
(0-20 \mathrm{~m})\end{array}$ & Anoxic zone & & & & $\begin{array}{l}\text { Surface water } \\
\end{array}$ & Anoxic zone & & & \\
\hline Coastal seawater, Northern South China Sea & $<8.2-8.6$ & $\sim 8.18(65 \mathrm{~m})$ & - & $\sim 1500-1900$ & & & & & & Dai et al, 2008 \\
\hline Seto Inland Sea & $8.15-8.26(0-10 \mathrm{~m})$ & $>7.96(40 \mathrm{~m})$ & & $\sim 1750-1950$ & - & $\sim 6.0-9.5(0-10 \mathrm{~m})$ & $>3.0(40 \mathrm{~m})$ & - & $\sim 9-26$ & Taguchi and Fujiwara, 2010" \\
\hline $\begin{array}{l}\text { Coastal seawater (Bay of Bengal) } \\
\text { Puget Sound Estuary, main basin (S }\end{array}$ & $\begin{array}{c}7.96-8.38 \\
805\end{array}$ & & 416-1062 & & & & & & 26.0-28.0 & Biswas et al., 2004 \\
\hline $\begin{array}{l}\text { Puget Sound Estuary, main basin (Summer) } \\
\text { Puget Sound Estuary, main basin (Winter) }\end{array}$ & $\begin{array}{l}8.05 \\
7.71\end{array}$ & $\begin{array}{l}7.83(>100 \mathrm{~m}) \\
7.73(>100 \mathrm{~m})\end{array}$ & - & 1884 & - & $\sim 5.74-8.20$ & 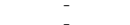 & - & & Feely et al, 2010 \\
\hline North Sea (English Coastal waters) & $\sim 8.10-8.16$ & & - & 190 & & $-4.07-4.66$ & - & & - & Feely et al., 2010 \\
\hline North Sea (French coastal waters) & $\sim 8.10-8.50 ; \sim 7.95-8.28$ & - & - & - & & 360.070 .000 & - & & - & Frankignoulle et al., 1996 \\
\hline Northern Gulf of Mexico (summer) & 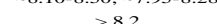 & $<6-80$ & - & - & & 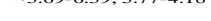 & & & - & Frankignoulle et al., $1996^{\circ}$ \\
\hline Northern Gulf of Mexico (spring) & -82 & $78-8.0$ & 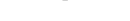 & - & & & & & - & Cai et al. 2011" \\
\hline & $8.10-8.1801$ & $771-7.93(10-37 \mathrm{~mm}$ & - & - & & $5.48-6.10$ & $0.10-2.79$ & & $0-31.2+2$ & $\begin{array}{l}\text { Caiet al. } 2011 \\
\text { Sunda and Cai, }\end{array}$ \\
\hline Monterey Bay L20 (pelagic), near Shore & $7.857-8.356$ (30 days) & 1.19-1.93(10-5) (m) & & & & -2 & $0.10=2.93$ & & 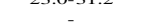 & $\begin{array}{l}\text { Sunda and Cai, } 2012 \\
\text { Hofinann et al. } 2011\end{array}$ \\
\hline Upwelling seawater (pelagic), Pt. Conception, Monterey Bay & $7.869-8.266$ (30 days) & & - & - & & & - & & - & Hofmann et al., 2011 \\
\hline $\begin{array}{l}\text { Upwelling seawater (pelagic), Pt. Ano Nuevo, Monterey Bay } \\
\text { North Pacific Ocean }\left(25-55^{\circ} \mathrm{N}, 150^{\circ} \mathrm{W} \text { ) }\right.\end{array}$ & $7.685-8.152$ (30 days) & $\sim 76-7,3(>500)$ & -1 & - & - & - & - & - & - & Hofmann et al., 2011 \\
\hline $\begin{array}{l}\text { North Pacific Ocean }\left(25-55^{\circ} \mathrm{N}, 152^{\circ} \mathrm{W} \text { ) }\right. \\
\text { Southern Ocean (Atlantic sector) }\end{array}$ & $\begin{array}{c}8.2-7.6 \\
8.060-8.123\end{array}$ & $-7.6-7.3(>500)$ & & - & - & -5 & - & & - & Byrne et al. 2010 \\
\hline $\begin{array}{l}\text { Southern Ocean (Atlantit sector) } \\
\text { Southern Ocean (Atlantic sector) }\end{array}$ & $8.060-8.123$ & - & $313-377$ & & 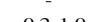 & $5.31-5.89$ & - & -5 & $\sim(-2)-13.8$ & Chierici et al, 2004 \\
\hline $\begin{array}{l}\text { Southern Ocean (Atlantic sector) } \\
\text { Cold-water, northeast Atlantic (5 sites: depths } 0-1930 \mathrm{~m} \text { ) }\end{array}$ & $\begin{aligned}-8.06-8.12 \\
<8.10-8.19\end{aligned}$ & $>7.92-8.06$ & - 313-377 & $=$ & $\begin{array}{l}\sim 0.2-1.0 \\
0.02-1.2\end{array}$ & - & - & - & $=$ & $\begin{array}{l}\text { Cherici et al., } 2004 \\
\text { Findlay et al, } 2014\end{array}$ \\
\hline $\begin{array}{l}\text { Submarine spring, Puerto Morelos, Mexico } \\
\text { lats }\end{array}$ & $7.143-8.048$ (30 days) & & - & & & & & & & Hofimann et al., 2011 \\
\hline $\mathrm{CO}_{2}$ vent, Ischia (South Zone), Italy & $6.699-8.129$ ( 30 days) & - & & & - & - & - & - & & Hofimann et al., 2011 \\
\hline $\mathrm{CO}_{2}$ vent, off Ischia Island, Italy (surface water at site $\mathrm{S} 1$ ) & $8.13-8.17(21$ days $)$ & & $304-346$ & $2120-2160$ & & & & & $18.0-19.7$ & Hall-Spencer et al, 2008 \\
\hline $\mathrm{CO}_{2}$ vent, off Ischia Island, Italy (surface water at site $\mathrm{S} 2$ ) & $7.35-8.16(21$ days $)$ & - & $314-2,626$ & $2120-2510$ & - & & - & & $17.8-20.0$ & Hall-Spencer et al, 2008 \\
\hline $\mathrm{CO}_{2}$ vent, off Ischia Island, Italy (surface water at site $\mathrm{S} 3$ ) & 6.07-7.37 (21 days) & - & 2,448-51,997 & $2510-4220$ & - & - & & - & $18.0-20.0$ & Hall-Spencer et al, 2008 \\
\hline $\mathrm{CO}_{2}$ vent, off Ischia Island, Italy (surface water at site $\mathrm{N} 1$ ) & $7.96-8.19$ (21 days) & - & $286-552$ & $2100-2240$ & - & - & - & - & $18.0-20.0$ & Hall-Spencer et al, 2008 \\
\hline $\mathrm{CO}_{2}$ vent, off Ischia Island, Italy (surface water at site $\mathrm{N} 2$ ) & $7.54-8.17$ (21 days) & - & 309-1,644 & $2130-2440$ & - & - & - & & $18.0-20.0$ & Hall-Spencer et al, 2008 \\
\hline $\mathrm{CO}_{2}$ vent, off Ischia Island, Italy (surface water at site N3) & $6.31-7.90(21$ days $)$ & & $654-29,885$ & 2280-3500 & & & & & $18.0-20.0$ & Hall-Spencer et al, 2008 \\
\hline $\mathrm{CO}_{2}$ vent, off Ischia Island, Italy (at site $\mathrm{P} 1$ on $3 \mathrm{~m}$ depth) & $8.15-8.18$ (21 days) & - & 296-322 & $2110-2130$ & - & - & - & - & $18.1-20.0$ & Hall-Spencer et al, 2008 \\
\hline $\mathrm{CO}_{2}$ vent, off Ischia Island, Italy (at site $\mathrm{P} 2$ on $3 \mathrm{~m}$ depth) & $8.13-8.20$ (21 days) & & $278-347$ & $2100-2160$ & & & & & 18.5 & Hall-Spencer et al, 2008 \\
\hline $\mathrm{CO}_{2}$ vent, off Ischia Island, Italy (at site $\mathrm{P} 3$ on $3 \mathrm{~m}$ depth) & 7.67-8.16 (21 days) & & $315-1,173$ & $2130-2390$ & & & - & & 19.0-19.5 & Hall-Spencer et al, 2008 \\
\hline $\mathrm{CO}_{2}$ vent, off Ischia Island, Italy (at site $\mathrm{P} 4$ on $3 \mathrm{~m}$ depth) & 6.98-8.14 (21 days) & & 334-6,253 & $2140-2670$ & & & & & 19.0-19.5 & Hall-Spencer et al, 2008 \\
\hline $\begin{array}{l}\text { Hiroshima Bay, Japan } \\
\text { Hiroshima }\end{array}$ & & & 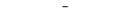 & - & & & & 143-448 $>$ $>$ & $19.5-22.1$ & Akane et al. 2004 \\
\hline Japan & - & - & - & - & - & - & & $7-1$ & - & Sakuawa et al, 2000 \\
\hline Seto Inland Sea, Japan & & & - & - & - & 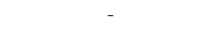 & & $40-191$ & - & Sakugawa et al, 1995 \\
\hline Tokyo Bay & - & - & & & - & - & & 20-207 & & Sakugawa et al., 1995 \\
\hline $\begin{array}{l}\text { Sagami Bay } \\
\text { Mediterian }\end{array}$ & & & - & - & - & & & $40-80$ & - & Sakugawa et al., 1995 \\
\hline $\begin{array}{l}\text { Mediteran, Israel coastal waters } \\
\text { Red Sea, Gulf of Aqqaba }\end{array}$ & & & - & - & $=$ & 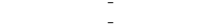 & - & $\begin{array}{l}10.0-800.0 \\
8-100\end{array}$ & - & $\begin{array}{l}\text { Heructean, } 1998 \\
\text { Herte tall }\end{array}$ \\
\hline Lagrangian, Atlantic Oceean & & & - & - & - & -5 & - & $23-55$ & te & Yuan and Shiller, 2001 \\
\hline $\begin{array}{l}\text { Underway, Atantic Ocean } \\
\text { Bermuda Atlantic Time Series Station }\end{array}$ & & & - & - & & & - & $27-47$ & - & Yuan and Shiller, 2001 \\
\hline
\end{tabular}


